\title{
Agricultural Modernization, Structural Change and Pro-poor Growth: Policy Options for the Democratic Republic of Congo
}

\section{Christian S. Otchia}

Received: 2 April 2014 / Revised: 19 August 2014 / Accepted: 18 November 2014 /

Published online: 12 December 2014

(C) 2014 Otchia; licensee Springer. This is an Open Access article distributed under the terms of the Creative Commons Attribution License (http://creativecommons.org/licenses/by/4.0), which permits unrestricted use, distribution, and reproduction in any medium, provided the original work is properly credited.

\begin{abstract}
This paper applies the framework for pro-poor analysis to welfare changes from a CGE-microsimulation model to analyze what are the better or worse models for agriculture modernization, and to estimate the contribution of growth and redistribution to changes in poverty in DRC. The findings indicate that labor-using technological change generates absolute and relative pro-poor effects whereas capital-using technological change leads to immiserizing growth. More importantly, the results suggest that labor-using technological change can be independently sufficient for reducing poverty via the income growth effects. This study also highlights how developing input supply networks, securing tenure among smallholders, and improving access to land for women are important for pro-poor agricultural modernization.
\end{abstract}

Keywords Agricultural modernization · Technological change · Pro-poor growth · Input reform · CGE-microsimulation

JEL Classification C68 $\cdot \mathrm{D} 33 \cdot \mathrm{O} 33 \cdot \mathrm{Q} 10 \cdot \mathrm{Q} 18$

\section{Introduction}

Agricultural transformation is essential for the Democratic Republic of Congo (DRC) because it has huge potential to spur growth and raise income. Agriculture employs most of the labor in DRC and produces the largest percentage of total value added. Figure 1 shows that agriculture employs 60.2 percent of the Congolese labor force and generates about 21 percent of total value added. Sectors such as textiles, chemicals, construction, and forestry only produce a small share of value added and contribute

C.S. Otchia $(\bowtie)$

Graduate School of International Development, Nagoya University, Furo-cho, Chikusa-ku, Nagoya 464-8601, Japan

e-mail: cotchia@gmail.com 
Fig. 1 Profile of sectoral employment and value added (2005). Source: Author's based on DRC national accounts (2005)

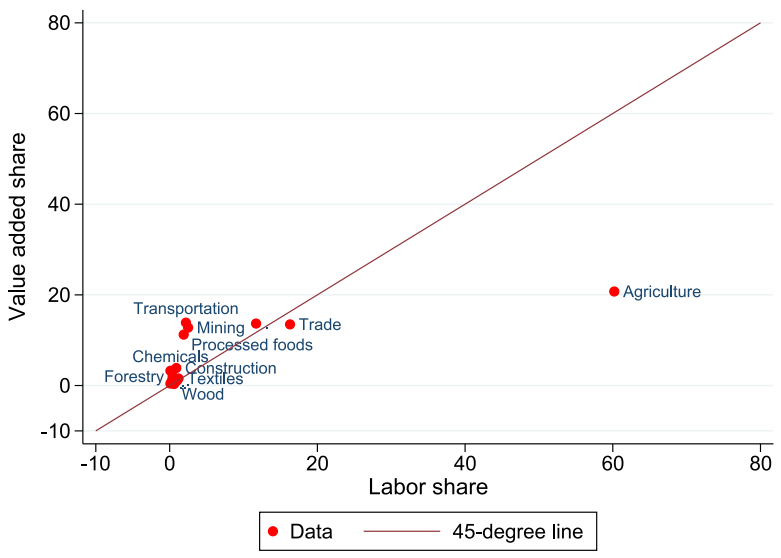

marginally to employment creation. Figure 1 further indicates that agriculture and trade sectors lie below the 45-degree line, meaning that the share of employment in these sectors is higher than the share of value added from these sectors. However, the largest gap between the contribution to value added and employment appears to be in agriculture. This indicates that agriculture has the lowest productivity in DRC's economy.

Agriculture is the most unproductive sector in DRC because of inconsistent and uncoordinated agricultural development strategies, coupled with conflict and the progressive withdrawal of the government from supporting agricultural activities. According to Otchia (2013b), government policy implemented since 1966 led to the collapse of large-scale commercial agriculture, favored subsistence agriculture, and distorted economic incentives against agriculture. In addition to this, the government removed all subsidies and price support measures to agriculture in 2002. Consequently, farmers use a rudimentary agricultural technology mostly based on outdated production methods and inputs. Agriculture also faces high transaction costs due to the lack of infrastructure most of which was destroyed during political conflicts. Low productivity in agriculture entails unstable and low paid jobs. As a result, an overwhelming proportion of agricultural workers are poor. Four out of every five rural poor work in agriculture. In urban areas, agriculture accounts for one-third of the poor.

Nevertheless, agriculture is still attracting labor in both urban and rural areas. According to Herderschee et al. (2012), agriculture provided employment for 10 million people in 2005 and 15 million in 2010. Despite the low productivity, labor accrues in agriculture because it can produce the amount of food necessary for their subsistence. This implies that most of the farming activities are of a small scale and aim to increase food security. Given its low productivity, increasing the amount of labor and land is the only way to raise production in agriculture. Labor flows to subsistence farming as it uses essentially manual work, whereas large-scale farmers tend to expand land. Indeed, DRC is far from reaching the agriculture frontier, as it uses only 11 percent of the 80 million hectares of arable non-forest land for agriculture. However, in recent years, much of agricultural land has been developed for export-oriented large- 
scale commercial agriculture. ${ }^{1}$ These agricultural investments are made by foreign investors to secure their own food needs. This constrains access to land for smallscale farmers.

Against this background, agricultural productivity improvement is the fundamental policy to initiate agricultural transformation and raise income of the poor (AlvarezCuadrado and Poschke 2011; Ngai and Pissarides 2007). The reason is that productivity improvement "pushes" labor out of agriculture and increases farmers' real wages; "pulls" jobs in sectors that use agriculture as inputs; and increase supply of affordable food in the economy. The empirical literature reports strong and robust effects of agriculture productivity on poverty (Thirtle et al. 2003; Irz et al. 2001; de Janvry and Sadoulet 2010). However, the magnitude of poverty reduction due to agricultural productivity growth varies largely across countries, depending on the way they developed and used new technologies (de Janvry and Sadoulet 2010).

The literature documents a range of policies to increase agriculture productivity and enhance income-increasing structural change. ${ }^{2}$ Among them, technological change has been acknowledged as the principal driver of productivity growth (OECD 2012; Morris et al. 2007; DFID 2006). However, it is worth mentioning that the innovation, selection, and adoption of new technologies depend on the agriculture frontier, factor endowment, and market imperfections. Hayami and Ruttan (1970) used data on agriculture inputs to assess how endowment drove the direction of technical change in the US and Japan during 1880-1960. They found that land abundance in the US favored labor-saving technological change while the land scarcity in Japan led to the development and adoption of land-saving technologies. As a mechanization strategy, labor-saving technological change consists of using tractors and machinery, whereas land-saving technological change focuses on biological and chemical innovations. A recent successful case of land-saving technological change occurred during the Green Revolution in Asia. The Green Revolution was an intensifying of input-based production characterized by the use of high-yielding and fertilizer-efficient new varieties of seed (rice and wheat). Policymakers initiated this type of agricultural transformation to increase food production and reduce hunger and malnutrition in the 1960s. Hence, it is conceptually clear that the Green Revolution increased agriculture and food production. Empirical results also indicate that it led to poverty reduction as it raised farmers' income and increased food affordability.

Though it is expected that agricultural productivity improvement tends to reduce poverty, the extent to which it reduces inequality and benefits small-scale farmers is still open to question. For instance, the pro-poorness of the Green Revolution has been disputed, since its effectiveness in reducing inequality is not straightforward. The main argument states that the Green Revolution worsened income distribution as it was biased in favor of larger farmers and missed the poorer subsistence smallscale farmers (Das 1998; Griffin 1979; Freebairn 1995; Goldman and Smith 1995).

\footnotetext{
${ }^{1}$ According to http://foreignpolicy.com/2013/12/17/green-rush/, half of the Democratic Republic of the Congo's agricultural lands are being leased to grow crops, including palm oil for the production of biofuels.

${ }^{2}$ There are policies within agriculture and outside agriculture. However, this research focuses on policies within agriculture.
} 
Furthermore, it increased landless farmers and the demand for unskilled labor, which in turn lowered wage laborers (Hazell and Ramasamy 1991; Glaeser 1987; Cleaver 1972).

Despite this, the experience of Asia points to a clear consensus on the role of strong public policies and investment in creating a pro-poor Green Revolution (Eicher 1995; Smale 1995; Hazell 2009). These policies include agricultural research and development, irrigation, rural roads, access to credit, and price support policies. In addition, those policies had been successful when they have been implemented together. However, there is no empirical assessment on the pro-poorness of technological change and the complementary rural development policies in Africa, especially in DRC.

This paper thus aims to assess what are the better and worse models for agricultural modernization in DRC. Agricultural transformation is qualified as a better model only if it is centered on small-scale farmers as most of them are poor and have limited resource endowment relative to other farmers. To put it differently, a better model for agricultural modernization produces pro-poor effects where poor households gain relative to the richer ones. Several recent studies have looked at the propoor effects of policies, particularly using CGE-microsimulation model (Boccanfuso et al., 2011, 2013a, 2013b; Annabi et al. 2008; Ravallion and Lokshin 2008). Most of the studies do not show factors behind the differences in the impacts of policy on pro-poor growth or decompose the changes in poverty into growth and distribution components, but rather show how poor benefit/lose relative to rich segments of the population. Boccanfuso and Kaboré (2004), however, did find that the relationship between poverty, growth, and inequality relationship is heterogeneous and conditional on context.

To look at the pro-poorness of different strategies for modernizing agriculture, I combine three techniques, namely a computable general equilibrium model, a household-survey based microsimulation, and least square regressions. I adopt a sequential approach that can be described in four steps. In the first step, I evaluate the effects of agricultural modernization strategies on employment, wages, and rents, and the price of goods and services. I use a CGE-microsimulation model that captures various links through which agricultural modernization affects households. These links include the return to labor and land, the price of goods, the impact on non-agriculture sector, and sectoral labor mobility. Then I feed the changes from the CGE model into a microsimulation model, which takes into account household heterogeneity in terms of factor endowments and consumption patterns, to generate welfare gains or losses at the household level. Using these welfare changes, in the third step I apply the propoor growth framework to assess which of the agricultural modernization strategies is pro-poor and the extent to which growth and redistribution contribute to welfare changes, following Annabi et al. (2008). Finally, I select a strategy that produced pro-poor welfare gains in the previous stage, and use a least square regression as in Ravallion and Lokshin (2008) to quantify the determinants of pro-poor agricultural modernization at the household level.

The rest of the paper is organized as follows. Section 2 presents an overview of the agricultural sector in DRC. Section 3 presents the theoretical framework of agricultural modernization, while Sect. 4 explains the features of the CGE-microsimulation model and presents an analytical framework for pro-poor analysis. Section 5 dis- 
cusses and presents the results of policy experiments. Finally, Sect. 6 provides a summary of the results and lessons for policymakers.

\section{Overview of the Congolese Agricultural Sector}

The Congolese economy depends on the agricultural sector, which contributes more than 20 percent of the country's GDP. However, it is important to note that the importance of agriculture is not a result of improved agricultural production. Rather, it is due to the marked reduction of mining production, which declined faster than agriculture. In recent years, agriculture became an urban phenomenon, especially for food security reasons and proximity to markets. Urban or peri-urban farming in the DRC is not only a response to the rise in food insecurity; it also serves as an income-generating activity because of the increasing demand for vegetables in cities and soaring food prices. As a result, the agricultural sector has become the second largest employer for urban workers after the trade sector. This section describes some key characteristics and features of agriculture in DRC, relevant to the problems under review. These are (a) land size and distribution; (b) fertilizer use; (c) production and productivity; (d) agricultural trade patterns; and (e) agriculture's contribution to poverty.

\subsection{Land Size and Distribution}

Land is a very important asset for DRC farmers for its economic, cultural and spiritual significance. Due to bad governance (corrupted judiciary system, weaken traditional land rights, flawed land law (uncertain land rights, outdated land registry), however, land has become the key driver of conflict in the eastern part of the country (Vlassenroot and Huggins 2005; Huggins 2010). The most core issue in conflicts over land concerns limited access to land, land succession problem, and inequitable distribution. There are other factors behind land issues in DRC, such as colonization, land grab, migration, and climate change (Long 2011; Chausse et al. 2012; African Union et al. 2012). The consequences of these measures and events are visible in all their extent: increased landless and reduced average land size.

For instance, the highly skewed nature of land distribution in DRC is evident if one looks at Fig. 2 where I plot the value of land per household, per capita and per adult across three locations, namely urban, peri-urban, and rural areas. The figures indicate that farms are very small; the average land holding per household is in order of 1.3 hectare (ha) in urban areas and around 2 ha in peri-urban and rural areas, whereas the median of land per household is 0.8 in urban areas, and 1 ha in peri-urban and rural areas. The median are about 50 percent lower than the mean, implying the existence of high land inequality. Moving to the per capita distribution, panel (b) of Fig. 2 shows that average land per capita is 0.3 hectares in urban areas, while it is 0.4 and 0.6 hectares in peri-urban and rural areas. Despite the dominance of small farms, it is interesting to note that the average land per capita is not much of issue as it ranks DRC among countries with more than an average of potential agricultural land. On average, land per adult is a bit more than half a hectare in urban areas but nearly 
(a) Land per household

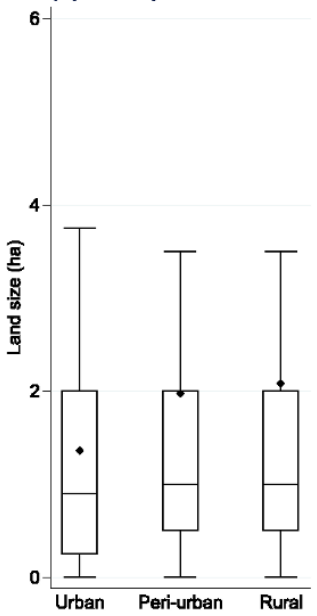

(b) Land per capita

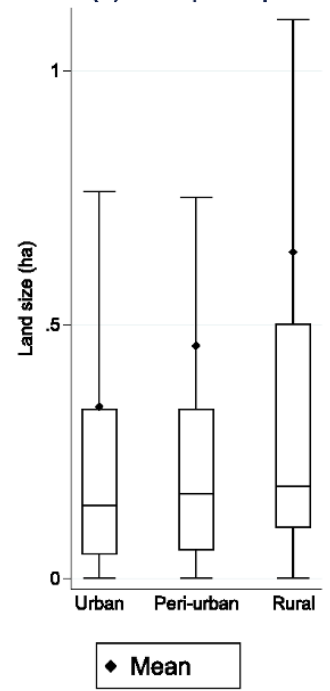

(c) Land per adult

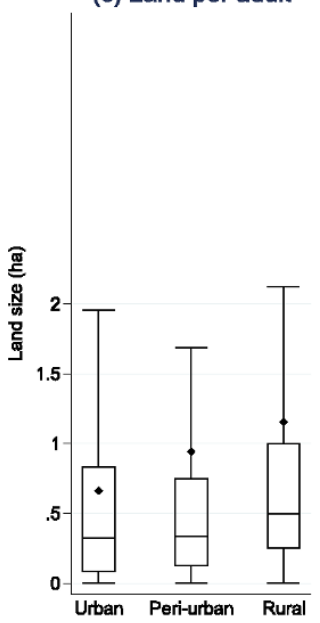

Fig. 2 Boxplots for land size

1 hectare in peri-urban and 1.15 hectares in rural areas. As one would expect, the average land per adult is significantly higher in rural areas because of migration to urban areas.

The significant discrepancies between mean and median land size suggest the limitation of the figures to assess land distribution in DRC. Therefore, I complement the land distribution analysis by decomposing the Gini coefficient of inequality between urban, peri-urban, and rural areas. In this study, I decompose the Gini coefficient into three components, namely a within-group inequality term, a between-group inequality term, and an overlap term. The within-group inequality term is a weighted sum of the inequalities calculated for each area (urban, peri-urban, rural), whereas weights depend on the population and land share of each area. The between-group inequality term is calculated on the total population where the land size of each person in the area is replaced by the average land size in the area where he lives. This component of inequality thus indicates the mean difference across areas. The overlap term is a residual term that arises because the areas' land size ranges overlap. It reflects the interaction effect among groups. ${ }^{3}$

Based on the figures on Table 1, it appears that the overall Gini coefficient of land per household is 0.46 , indicating that land inequality is very high in DRC. Table 1 also shows a more unequal land distribution in terms of land per capita, as the Gini of 0.56 indicates. Comparing these estimates to those of the sub-region reported by Jayne et al. (2003), it appears that DRC has an unequal land distribution than Zambia and Mozambique, where the Gini index of land per household is 0.44 and 0.45 , respectively, and the Gini of land per capita is 0.50 and 0.51 . Jayne et al. (2003) report higher Gini of land per household for Rwanda (0.52), Kenya (0.55) and Ethiopia

\footnotetext{
${ }^{3}$ See Mookherjee and Shorrocks (1982), Lambert and Aronson (1993) and Lambert and Decoster (2005).
} 


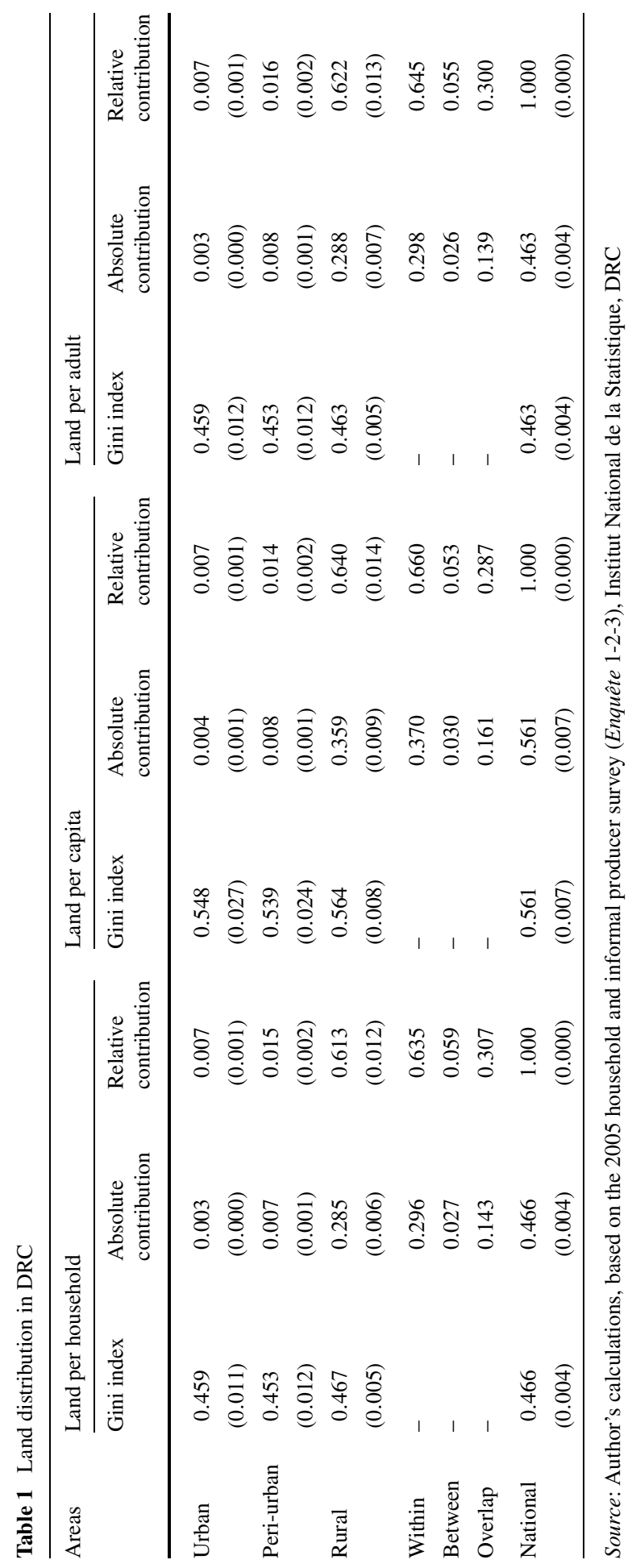


Fig. 3 Fertilizer use. Source: Author's creation based on FAOSTAT

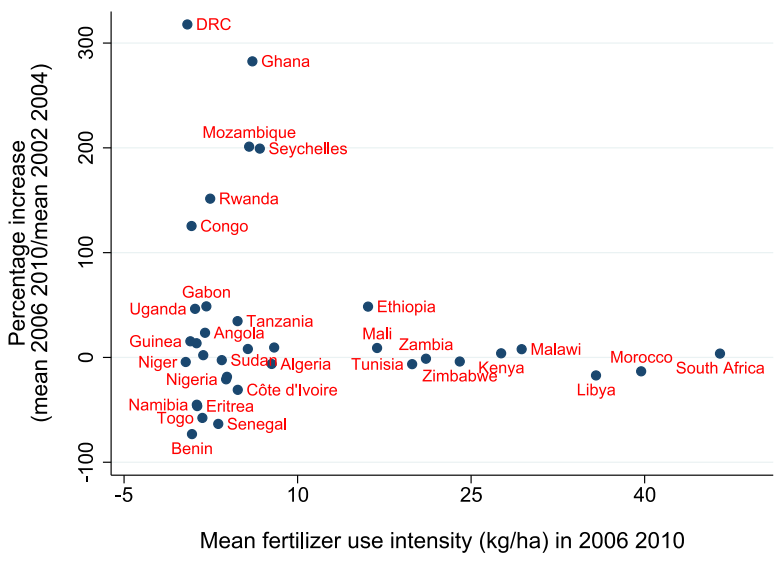

(0.55) than DRC. In addition, the distribution of land per capita in DRC is similar to Ethiopia (0.56) but more unequal than in Rwanda (0.54) or Ethiopia (0.55).

Furthermore, Table 1 indicates that land distribution is more unequal in rural area, as the Gini of rural area is higher for land per household, land per capital, or land per adult. Similarly, rural area is the most responsible of land inequality, as it contributes to 61 percent of total land inequality. This leads the within-area inequality become high in explaining land inequality than the between-area inequality. The high share of within-sector term calls for attention in reducing land inequality in rural sector.

\subsection{Fertilizer Use}

Now, I turn to the use of fertilizer in DRC. Figure 3 compares the use of fertilizers in DRC and some African countries. One can see that DRC uses less fertilizer than its neighboring countries. Between 2006 and 2010, the average intensity of fertilizer use in DRC was only $0.47 \mathrm{~kg} / \mathrm{ha}$, while it reached 46.51 and $36.69 \mathrm{~kg} / \mathrm{ha}$ in South Africa and Morocco. High cost of fertilizers is the main reason that limits the fertilizer use in DRC. Most of these costs are due to imports and transportation costs, as DRC imports about 10,000 metric tons of fertilizer annually. According to Nweke et al. (2000), most of farmers in DRC have low incentive to invest in fertilizer because imported wheat and rice are available at competitive price in nearby commercial markets. Unavailability of credit and support price measures for dealers and farmers plays a major role in limited use of fertilizer. In fact, fertilizer import business in DRC is too small and unstable to ensure its survival.

The other factors for low fertilizer use are the lack of adequate knowledge about fertilizers, bad quality of available fertilizers, poor extension services, and local farming practice. Mumvwela (2004) stated that farmers in western DRC use also less of livestock manure that are available. Despite the low intensity of fertilizer use, it is interesting to see that DRC is rapidly increasing the amount of fertilizer. Figure 3 also shows that DRC increased by 300 percent the use of fertilizer between 2006-2010 and 2002-2004. Nevertheless, there is still much to do, as yields have not responded yet to the increase of fertilizers. 


\subsection{Agricultural Production and Productivity Trends}

Table 2 shows the growth rates of production of the main agricultural products in the DRC between 1960 and 2010. The main food crops (cassava, plantains, and maize) accounted for 80 percent of total agricultural production, while cash crops represented less than 15 percent.

Data in Table 2 reveal a widely varying pattern of production growth rates among the different agricultural products over 1960-2010. This is the result of uncoordinated agricultural development strategies, coupled with conflict and the progressive withdrawal of the government from supporting agricultural activities. Cash crops were the backbone of DRC agriculture in the 1960s. In particular, palm oil generated half of total export earnings and made the DRC the second largest exporter of this crop in the world. As a result of a succession of policy strategies and measures, however, the production of cash crops (rubber, sugar, coffee, and cotton, in addition to palm oil) declined starting in the early 1970s. For instance, the production of palm oil fell from 224,000 metric tons in 1961 to 187,000 metric tons in 2011. This coincided with the implementation of goal no. 80 of a 10-year plan of industrialization through domestic and external loans. The collapse of cash crop production was accelerated by "Zaïrianization" (1973-1974), a policy of expropriation of foreign-owned production units by the government, which then handed them over to nationals. This policy led to the collapse of large-scale commercial agriculture, favored subsistence agriculture, distorted economic incentives against agriculture (Otchia 2013a), and led to conflicts. Growth in palm oil production resumed in the 1990s as a result of another agricultural and rural development plan, Le Plan Directeur, ${ }^{4}$ but could not be sustained because of looting (1991-1993) and war (1998-2002).

War and civil conflict in the 1990s negatively affected production of food crops as well. Table 2 indicates that sweet potatoes, plantains, rice, cassava, and bananas experienced a large drop during 1990-2000. In spite of this decline, the agricultural sector has continued to serve as the backbone of the Congolese economy. Growth of agricultural production, especially food crops, resumed during 2000-2010. Production of soybeans, which are grown extensively for their nutritional qualities, grew by 25.6 percent, while that of plantains and bananas grew by 14.4 and 13.4 percent, respectively. However, as long as production technology remains rudimentary and producers lack improved varieties and inputs, the growth of food crop production continues to depend on available quantities of the basic production factors of land and labor. For example, the harvested area of sweet potatoes and paddy rice grew by 23.3 and 11.7 percent, respectively, from 2000 to 2010.

Concerning agricultural productivity, panel (a) of Fig. 4 displays agricultural land productivity and the per capita capital stock in land development, while panel (b) plots agricultural labor productivity and per capita capital stock in machinery and equipment. ${ }^{5}$ As can be seen, land productivity increased between 1980-1989 and

\footnotetext{
${ }^{4}$ This plan aimed to design regional and sectoral strategies to promote food security, and to define the role of the state and the private sector.

${ }^{5}$ Land productivity indicates the total output per hectare of agricultural land, whereas labor productivity is expressed as the value of agricultural production per agricultural worker. Both land and labor productivity are expressed in 2004-2006 USD.
} 


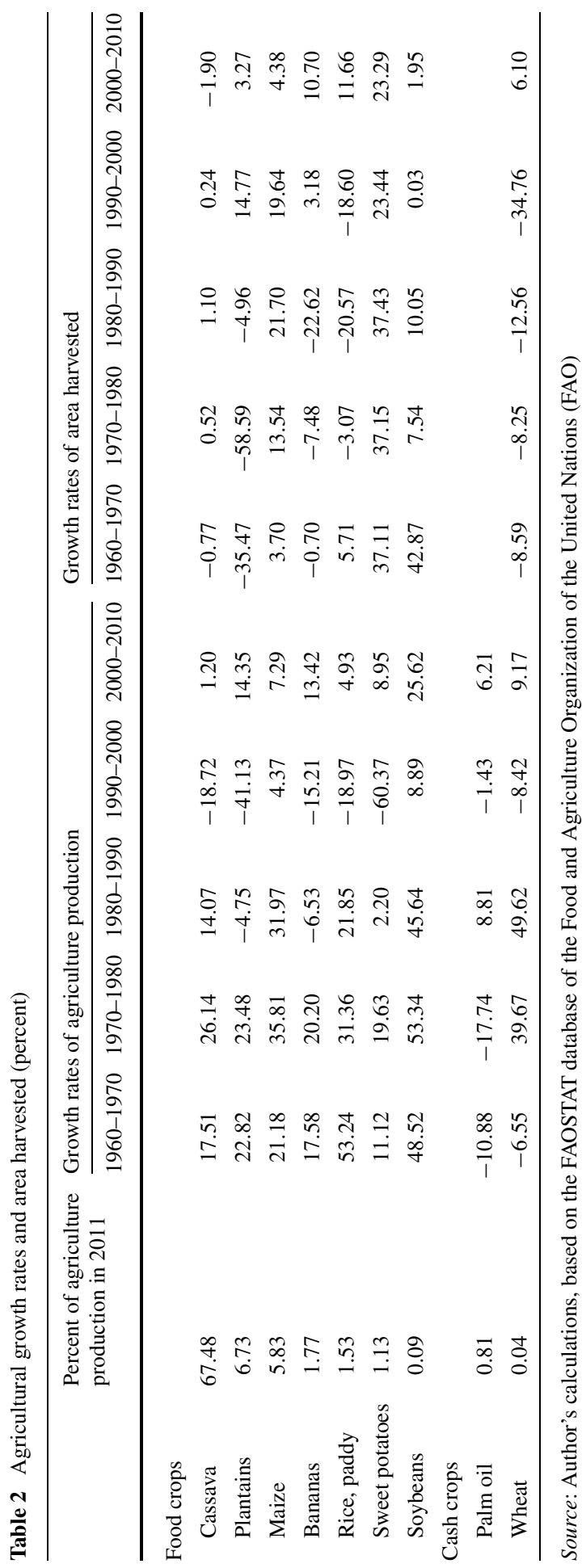



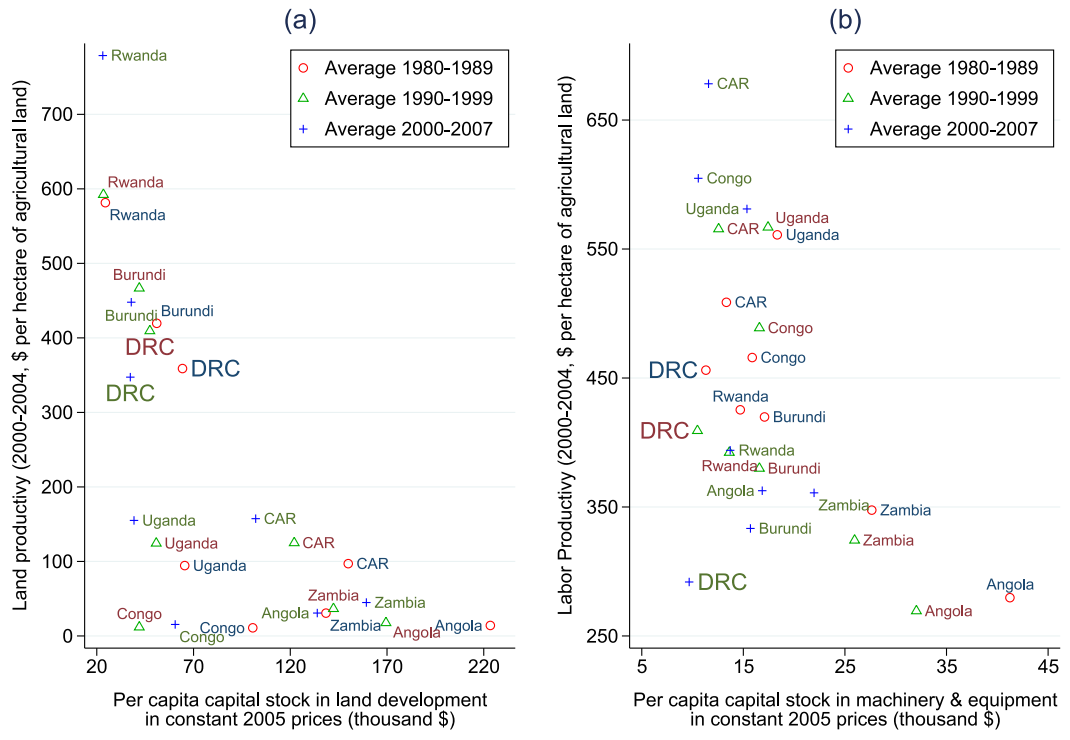

Fig. 4 Labor and land productivity in DRC and neighboring countries. Source: Author's creation based on FAOSTAT

1990-1999, but dropped afterward due to the collapse of infrastructure and frequent displacement of farmers during the war period. Labor productivity, on the other hand, decreased continuously starting in 1980-1989, and then fell drastically between 1990-1999 and 2000-2007. Land and labor productivities in DRC are low and decreasing for various reasons, including the lack of investment in accumulating capabilities, low fertilizer use, land size, war and displacement, the informal character of agriculture, and the rudimentary nature of technology used in this sector. For instance, Fig. 4 indicates that per capita stock in land, and machinery and equipment development is decreasing since 1980-1989.

\subsection{Agricultural Trade Patterns}

Exports from the DRC, after having more than doubled from 1961-1980, decreased sharply during 1980-2000, as shown in Table 3. The reason is that the development policies implemented during the latter period, such as Zaïrianization, undermined the viability of large-scale agricultural projects and disrupted the maintenance of rural infrastructure and support services, as discussed in the previous section. Exports of palm oil, rubber, and cotton collapsed in the 1990s, and in later years DRC agricultural exports came to be dominated by bran of wheat and coffee, which amounted to 62.8 percent of such exports in 2010 .

Since the level of food production is low, the DRC dependency on imported food has increased. Table 4 indicates that food imports increased approximately 40 -fold between 1960 and 2010, from \$23 million in 1960 to \$977 million in 2010. Major imports included flours of wheat and maize, sugar, palm oil, and meat. As can also be seen in the table, the DRC only started to import significant amounts of maize, sugar, and palm oil in 2000 . 
Table 3 Agricultural exports, selected years

\begin{tabular}{|c|c|c|c|c|c|c|}
\hline & 1961 & 1970 & 1980 & 1990 & 2000 & 2010 \\
\hline Total agricultural exports (thousand constant \$) & 107,340 & 112,196 & 234,839 & 139,080 & 39,308 & 75,120 \\
\hline \multicolumn{7}{|l|}{ Export share in total agricultural exports (percent) } \\
\hline Bran of wheat & 0.00 & 0.00 & 16.25 & 14.63 & 41.12 & 52.09 \\
\hline Cocoa beans & 1.23 & 1.43 & 2.26 & 3.28 & 4.84 & 2.09 \\
\hline Coffee, green & 8.27 & 16.74 & 40.16 & 63.54 & 50.02 & 10.75 \\
\hline Cotton lint & 3.71 & 2.48 & 1.19 & 0.00 & 0.34 & 0.00 \\
\hline Palm oil & 37.62 & 34.08 & 5.42 & 0.00 & 0.00 & 0.90 \\
\hline Rubber nat dry & 9.18 & 9.86 & 10.55 & 4.25 & 0.27 & 1.03 \\
\hline Tea & 1.23 & 1.73 & 0.79 & 1.59 & 0.15 & 0.16 \\
\hline Other & 38.76 & 33.69 & 23.37 & 12.71 & 3.25 & 32.98 \\
\hline Total & 100.00 & 100.00 & 100.00 & 100.00 & 100.00 & 100.00 \\
\hline
\end{tabular}

Source: Author's calculations, based on FAOSTAT

Table 4 Food imports, selected years

\begin{tabular}{lllllll}
\hline & 1961 & 1970 & 1980 & 1990 & 2000 & 2010 \\
\hline Total food imports (thousand constant \$) & 22,792 & 61,887 & 156,900 & 241,393 & 214,424 & 977,293 \\
Import share in total agricultural imports (percent) & & & & & & \\
Wheat & 0.03 & 0.00 & 39.60 & 29.36 & 21.34 & 28.66 \\
Flour of maize & 0.00 & 0.00 & 0.00 & 0.00 & 7.47 & 13.18 \\
Flour of wheat & 32.47 & 27.82 & 1.76 & 11.37 & 18.03 & 9.68 \\
Sugar raw centrifugal & 0.00 & 0.00 & 0.00 & 0.00 & 7.79 & 8.95 \\
Palm oil & 0.00 & 0.00 & 0.00 & 0.00 & 0.94 & 5.61 \\
Chicken meat & 0.65 & 0.41 & 0.95 & 4.30 & 2.52 & 4.19 \\
Rice-total (rice milled equivalent) & 14.81 & 8.52 & 6.19 & 16.60 & 10.95 & 3.41 \\
Malt & 15.43 & 12.43 & 4.76 & 4.88 & 3.14 & 3.31 \\
Other & 36.60 & 50.82 & 46.74 & 33.49 & 27.83 & 23.01 \\
Total & 100.00 & 100.00 & 100.00 & 100.00 & 100.00 & 100.00 \\
\hline
\end{tabular}

Source: Author's calculations, based on FAOSTAT

\subsection{Agriculture and Poverty}

Figure 5 plots the breakdown of the poverty headcount by sectors of activity, ${ }^{6}$ i.e. agriculture and other sectors, and compares it across urban and rural areas. This allows for evaluating the contribution of agriculture to poverty reduction. The figure clearly shows that the agricultural sector is home to the poor. In rural areas, where the poverty rate is extremely high, 83.4 percent of poor households work in agricul-

\footnotetext{
${ }^{6}$ The consumption per adult equivalent used in this study was adjusted using FAO's adult equivalent scale from FAO/WHO/UNU (2004) and Collier et al. (2008). 
Fig. 5 Distribution of poverty by economic sector in 2005 (percent). Source: Author's computations, based on the 2005 household and informal producer survey (Enquête 1-2-3)

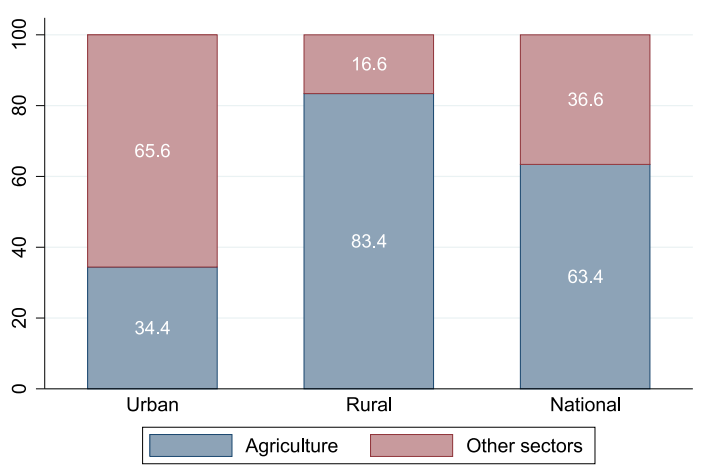

ture, while only 16.6 percent of the rural poor work in other sectors. In urban areas, the agricultural sector accounts for 34.4 percent of the poor population, which is still very high compared to the trade and transportation sectors. ${ }^{7}$ At the national level, the share of poor households that work in agriculture is 63.4 percent. It can thus be concluded that high poverty rates and the recent rise in rural poverty are at least partly related to the fall in labor and land productivity in agriculture described in Sect. 2.3.

Turning to the structure of budget shares and their distribution across groups, Table 5 reports a product-disaggregated breakdown of consumption expenditure by deciles of the income distribution. Here the interest is in examining how the expen-

Table 5 Distribution of consumption by expenditure group (percent)

\begin{tabular}{|c|c|c|c|c|c|c|c|c|c|c|}
\hline \multirow[t]{2}{*}{ Products } & \multicolumn{10}{|c|}{ Expenditure group (decile) } \\
\hline & 1 & 2 & 3 & 4 & 5 & 6 & 7 & 8 & 9 & 10 \\
\hline Food consumption & 72.1 & 72.0 & 71.8 & 71.1 & 70.2 & 68.9 & 71.3 & 68.0 & 64.8 & 52.7 \\
\hline Marketed & 40.1 & 40.2 & 41.8 & 42.3 & 43.9 & 47.1 & 51.7 & 51.5 & 54.8 & 48.5 \\
\hline Home-produced consumption & 32.0 & 31.8 & 30.0 & 28.8 & 26.3 & 21.8 & 19.6 & 16.5 & 10.0 & 4.2 \\
\hline Beverage and tobacco & 2.7 & 2.4 & 2.3 & 2.2 & 2.3 & 2.1 & 2.8 & 2.2 & 2.8 & 1.9 \\
\hline Clothing and footwear & 3.5 & 3.9 & 4.8 & 4.8 & 4.7 & 4.6 & 4.2 & 4.7 & 4.3 & 6.0 \\
\hline Housing, electricity, gas, water & 15.8 & 14.3 & 13.6 & 12.9 & 14.0 & 13.7 & 12.3 & 13.2 & 13.8 & 16.2 \\
\hline Medical care & 2.8 & 2.7 & 2.6 & 2.6 & 2.6 & 3.1 & 2.5 & 3.0 & 2.9 & 4.2 \\
\hline Transportation and communications & 0.2 & 0.7 & 0.8 & 1.3 & 1.5 & 2.1 & 1.7 & 2.8 & 3.9 & 8.6 \\
\hline Education & 0.8 & 1.1 & 1.1 & 1.3 & 1.3 & 1.7 & 1.5 & 1.6 & 1.7 & 3.0 \\
\hline Recreation and culture & 0.2 & 0.4 & 0.4 & 0.4 & 0.5 & 0.6 & 0.5 & 0.7 & 0.8 & 1.2 \\
\hline Restaurant and hotels & 0.9 & 0.7 & 0.5 & 1.1 & 0.8 & 1.0 & 0.8 & 1.3 & 2.2 & 2.8 \\
\hline Other services & 1.1 & 1.9 & 1.9 & 2.2 & 2.1 & 2.3 & 2.2 & 2.4 & 2.8 & 3.3 \\
\hline Total & 100.0 & 100.0 & 100.0 & 100.0 & 100.0 & 100.0 & 100.0 & 100.0 & 100.0 & 100.0 \\
\hline
\end{tabular}

Source: Author's calculations, based on the 2005 household and informal producer survey (Enquête 1-2-3)

\footnotetext{
${ }^{7}$ In the DRC, the trade and transportation sectors account for 20.7 and 9.1 percent, respectively, of employment of the urban poor.
} 
diture allocation across different consumption items evolves with the income level of the household. Several points are worth noting. Looking first at food expenditure, it is important to highlight the importance of food consumption in Congolese households' expenditure. Table 5 shows that Congolese households allocate the highest share of their expenditure to food consumption, and that this share decreases for rich households, following Engel's Law. Apart from food consumption, the category that includes housing, electricity, gas, and water represents the second largest expenditure item. The share of this category is almost homogeneous across all households, averaging 14 percent of total expenditure. The expenditure breakdown implies that after households cover their needs in food and housing, they have little money left for other services such as education and medical care. This is especially true for poor households: as can be seen, the share of education in total expenditure for the three lowest deciles is close to 1 percent.

In order to obtain more detailed information on food consumption patterns, Table 5 disaggregates food expenditure into market goods consumption and home-produced consumption. The food consumption pattern varies significantly using this disaggregation. Market food consumption represents 40 percent of poor households' expenditure, and this share increases with income. This means that rich households spend a larger share of their income on market goods than poor households. Looking at the home-produced consumption pattern also provides some important insights for policymakers. Home-produced consumption represents 32 percent of total expenditure for the poorest decile, which is approximately half of their food consumption expenditure, but this share declines significantly with income. It is 26.3 percent for the fifth income group decile, 10 percent for the ninth decile, and 4 percent for the richest decile.

Figure 6 extends the expenditure analysis by plotting the kernel density estimates of urban and rural households for food consumption. ${ }^{8}$ The figure plots the estimated density function of food consumption per adult equivalent for urban and rural households. It can be clearly seen that the distribution of the log of food consumption per adult equivalent for urban households is skewed to the left, while for rural households, the distribution is slightly skewed to the right. Two vertical lines represent the food expenditure poverty line for urban and rural areas. ${ }^{9}$ This enables one to assess the potential impact of growth on poverty reduction. The figure shows that the distance between the poverty line and the mode of urban per capita expenditure distribution is not large. From a poverty reduction policy perspective, this implies that it would require only a very small increase in per adult equivalent food consumption to move many households out of poverty in urban areas. In rural areas, however, the mode of the density function is quite far from the rural food poverty line. This indicates the need for poverty reduction policies capable of increasing incomes of the poor more

\footnotetext{
${ }^{8}$ In this study, I apply kernel density instead of a regression of food expenditure on income per capita in urban and rural areas because the main focus is to analyze the distribution of food expenditure relative to the poverty line.

${ }^{9}$ The food expenditure poverty lines were taken from the National Statistics Institute, which established the food expenditure poverty line at 123,070 Congolese francs for urban areas, and at 82,755 Congolese francs for rural areas. I thus represent the log of the urban food expenditure poverty line by the solid vertical line at the value of 11.72 and the log of the rural food expenditure poverty line by the dashed vertical line at 11.32 .
} 
Fig. 6 Kernel density function of households by per adult equivalent food consumption Source: Author's computations, based on the 2005 household and informal producer survey (Enquête 1-2-3)

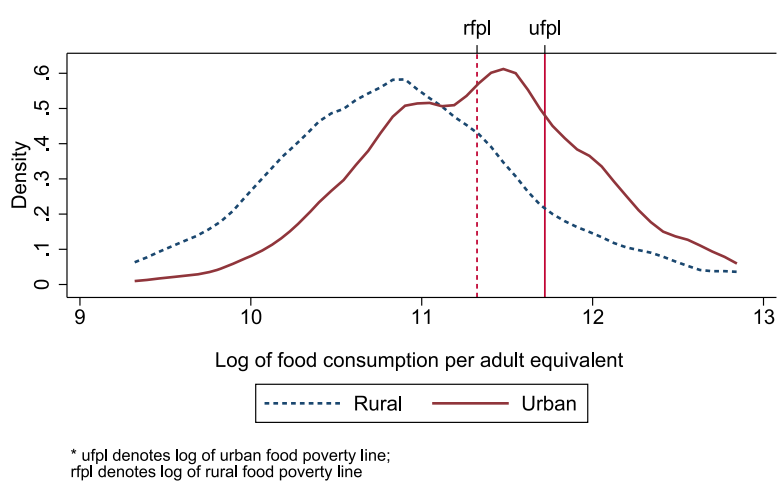

in the rural sector than in the urban sector in order to achieve similar reductions in poverty rates.

\section{Theoretical Consideration}

The literature on technological change in agriculture documents that countries tend to adopt the technology that can raise the productivity of the scarce factor or the factor with the lowest quality. Countries with scarce labor but abundant land and capital tend to adopt labor-saving technologies such as tractors and machinery. Countries with scarce land but abundant labor tend to adopt land-saving types of technologies such as chemical and biological high-yield technologies. Hayami and Ruttan (1985) provide a theoretical framework of this type of biased technological change based on the induced innovation hypothesis. According to this theory, innovation is induced as a response to changes in relative prices, which push firms to innovate in order to use less of the resource that has become more expensive. However, the hypothesis of biased technical change as hypothesized by Hayami and Ruttan may not hold in low income and sub-Saharan countries (Cuffaro 1997). In most of these countries, land and labor are abundant, but capital is scarce, and land inequality is high so that most of the farmers are smallholders. Thus, the theory of induced innovation cannot hold for the following reasons: (1) demand for innovation for small- and large-scale farms is different; (2) small- and large-scale farms have different influence on public research; (3) imported technology is absent in induced innovation theory.

In this study, the concept of pro-poor agricultural modernization refers to the advancement of agriculture technologies and institutions that improve the poor and small-scale farmers' welfare relative to rich large-scale farmers. This means that agricultural modernization includes mechanization strategy as part of technological change and the modernization of agriculture behavior, structure and institutions. The choice of the technology, which depends on the factor price and public policies, must be centered on the technological need of small-scale farmers.

The process of agriculture modernization includes mechanization and chemicalization. Mechanization comes with higher capital intensity whereas chemicalization implies that farmers adopt practices that increase the efficiency in the use of fertilizer and chemicals required to produce a certain level of outputs. This scheme includes 
also organic farming that maintains soil fertility to avoid the overuse of chemicals. Given the actual price and subsidies level, this technological path enables farmers to make effective and efficient use of the limited amount of fertilizer. These practices include crop rotation or integrated livestock crop rotation, intercropping, cover cropping or green manure, and composting waste materials. Finally, it is worth noting that achieving agricultural mechanization requires institutional changes that increase trust and encourage the private sector to adapt progressively proven technologies to local practices and production modes (Thirtle et al. 1998). In the case of DRC, public interventions are required to improve access to markets for inputs, outputs and finance, as transaction costs are very high.

\section{Methods}

To evaluate the pro-poorness of agricultural modernization-led growth, I adopt a sequential approach that combines a CGE model to a microsimulation model augmented to incorporate a pro-poor growth framework. The empirical strategy proceeds in four steps, as Fig. 7 depicts. I first use the CGE model to generate the effects of agricultural modernization strategies on employment, wages and rents, and the price of goods and services. Then I transmit these changes into a microsimulation model, which takes into account household heterogeneity in terms of factor endowments and consumption patterns, to generate welfare gains or losses at the household level. Using these changes in welfare, I apply the pro-poor growth framework to assess which of the agricultural modernization strategies is pro-poor, and the extent to which growth and redistribution contribute to welfare changes. Finally, I select a strategy that produced pro-poor welfare gains in the previous stage, and use a least square regression to explain its characteristics.

\subsection{Congolese Computable General Equilibrium Model}

The general specification of the Congolese CGE model follows the basic structure of the single-country model as described by Dervis et al. (1982). However, I closely follow Arndt et al. (2000) and Lofgren et al. (2013) for the specification of many structural and empirical features of the Congolese economy, namely an explicit modeling of trade and transportation costs for marketed commodities and relatively detailed description of home production. A full description of the CGE model can be found in Otchia (2014).

The Congolese CGE model is mainly calibrated to the social accounting matrix of the DRC for the year 2005 (Otchia 2013a). However, additional data were required to fully run the CGE model, including household demand elasticities, trade elasticities, and production elasticities. Household demand elasticities include income elasticity and the Frisch parameter and were estimated based on the Enquête 1-2-3 survey data. ${ }^{10}$ Trade elasticities include elasticities for the Armington and transformation

\footnotetext{
${ }^{10}$ The Enquête 1-2-3 is a mixed household-informal producer survey on employment, the informal sector, and consumption conducted in 2005 by the DRC's National Statistics Institute (Institut National de Statis-
} 


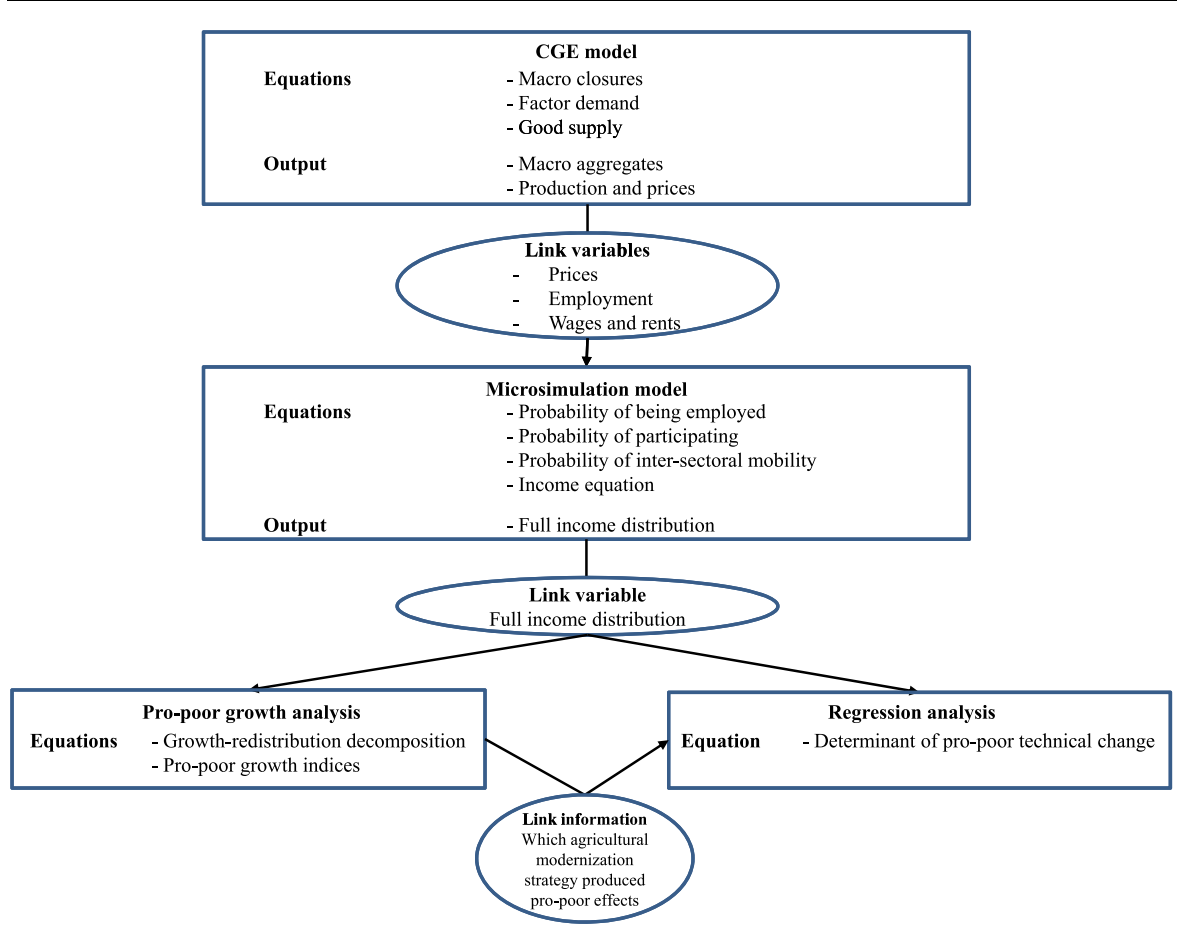

Fig. 7 CGE-microsimulation augmented with pro-poor growth framework

functions. Armington elasticities represent the elasticity of substitution in demand between imported commodities and domestic goods; whereas transformation elasticities include substitution elasticities among primary inputs in the value-added production function. For the case of the Congo, no trade elasticity was found due to the lack of time series data. Therefore, trade elasticities used in this study are from the Global Trade and Analysis Project based on Dimaranan (2006). Finally, production elasticities, which are drawn from the empirical CGE literature for African economies, vary between 0.3 and 1.2..$^{11}$

\subsection{Microsimulation Model}

The microsimulation model includes 12,098 households from the Enquête 1-2-3. My framework posits that agricultural technological change affects household income

tique). This survey is carried out in three phases. The first phase collects information about employment and households' economic condition and activities. The data collected through the first phase are used to identify household unincorporated enterprises (households whose production unit is not incorporated as a legal entity separate from the owner), which serve as statistical units for the next phase. The goal of the second phase is to provide information on business conditions, economic performance, and production linkages of the household unincorporated enterprises. Finally, the third phase uses the typical household budget survey to collect information on household consumption.

${ }^{11}$ Production elasticities which include factor substitution elasticities, take lower value $(0.3 \sim 0.8)$ for agriculture, forestry and mining. 
through channels such as changes in price of goods and services, changes in employment, and changes in the return to factors of production. The microsimulation model has two building blocks: a labor participation model and an accounting equation. Based on Magnac (1991) and Cogneau and Robilliard (2001), I specify a labor participation model to estimate changes in the labor conditions. Specifically, I use the labor participation equations to estimate the probability to participate in the labor market. Later, I use these probabilities to allocate labor in the microsimulation model based on changes in employment levels from the CGE model. The second component of the microsimulation transmits changes in commodity and factor prices following Otchia (2014).

The labor participation model has four components: (1) a probit model of the decision to participate in the labor market, (2) a multinomial probit model of the allocation of workers across sectors, (3) a bivariate probit model of the sectoral labor mobility, and (4) a rule for labor allocation and wage determination. The model assumes that workers can move from unemployment to employment status (or the opposite) and can move from across sectors. ${ }^{12}$ In the first stage, I estimate the choice of individuals to participate or not in the labor market. I run a probit model of employment to predict these probabilities, based on individual and households characteristics. The equation of the model is

$$
\lambda_{i}=\operatorname{prob}\left(I_{i}=1 \mid \mathbf{z}_{i}\right)=f\left(\mathbf{z}_{i} \boldsymbol{\alpha}+u_{i}\right)
$$

where $\mathbf{z}_{i}$ represents individual and household characteristics of the household head such as age, gender, education, household composition; $I_{i}$ is a binary variable which takes 1 if the household head is employed and 0 otherwise; and $u_{i}$ is an error term. Similarly, I use a multinomial probit model to estimate the probability to be employed in each of the economic sectors, relative to the probability to be unemployed.

The second stage of the microsimulation model uses a bivariate probit model to estimate the decision of current workers to move from one sector to another. This model estimates the probability of workers to be employed in the new sector given their current employment status.

In the third step, I transmit employment levels taken from the CGE model into the microsimulation and determine which households are affected based on the job queuing approach (Bibi et al. 2010). I rank the unemployed households by the decreasing order of their probability of being employed. Then I use the changes in employment from the CGE model to simulate the number of households who will be employed, starting from households with higher probability. The number of workers is calculated by multiplying the variation from the CGE model to sectoral employment and their labor income is the sectoral and skill level average. For sectors where employment shrinks, I rank employed households by the decreasing order to their probability of being unemployed. Given the changes from CGE model, I assign them the status of unemployed and their wage is set to zero.

When the demand for labor in one sector is higher than the supply from unemployment, I allow employed households to move to the sector with lack of supply

\footnotetext{
${ }^{12}$ This is consistent with the labor market assumption in the CGE model, where labor moves to equalize wage.
} 
based on their probability to move to other sectors. There is no cost of entry to the new sector as the CGE model assumed that labor moves to equalize wage.

In the final stage, I feed the changes in factor income $\left(d w_{l} / w_{l}\right)$, marketed commodities prices $\left(d p_{g} / p_{g}\right)$, and producer prices $\left(d p_{h g} / p_{h g}\right)$ obtained from the CGE model into the accounting equation to determine welfare gains or losses of each of the 12,098 households. The first-order welfare change function $d W_{h} / y_{h}$ is given as ${ }^{13}$

$$
d W_{h} / y_{h}=\sum_{l} \emptyset_{h}^{l}\left(d w_{l} / w_{l}\right)-\sum_{g} \theta_{h}^{g}\left(d p_{g} / p_{g}\right)-\sum_{h g} \theta_{h}^{h g}\left(d p_{h g} / p_{h g}\right)
$$

where $\emptyset_{h}^{l}$ is the share of factor $l$ in factor income of household $h, \theta_{h}^{g}$ is the share of marketed good $g$ in the total consumption expenditure of household $h, \theta_{h}^{h g}$ is the share of home-produced good $g$ in the total consumption expenditure of household $h$, and $y_{h}$ is the household income.

\subsection{Growth-Redistribution Decomposition and Pro-poor Growth Analysis}

In this study, I apply the pro-poor growth framework on the welfare changes from the microsimulation to assess the pro-poorness of agricultural modernization strategies. I follow Kakwani and Pernia (2000) to decompose the total changes in welfare into two components: the pure growth effect and the pure inequality effect. Let $L_{B}$ denote the distribution of income before agricultural modernization and $L_{A}$, the distribution of income after agricultural modernization. Then I write the growth rate in the mean income $\gamma$ as

$$
\gamma=\frac{\mu_{A}-\mu_{B}}{\mu_{B}}
$$

where $\mu_{B}$ and $\mu_{A}$ are the mean of income before and after agricultural modernization. Thus, I define the pure growth effects $G$ as the proportional change in welfare when the mean income changes but the distribution remains unchanged. The expression for the growth effects $G$ is

$$
G=P\left(\mu_{A}, L_{A}\right)-P\left(\mu_{B}, L_{A}\right)
$$

or alternatively

$$
G=P\left(\mu_{A}, L_{B}\right)-P\left(\mu_{B}, L_{B}\right) .
$$

Equivalently, the income effect depicts the change in welfare when inequality changes, but the mean income remains constant. This can be expressed as

$$
R=P\left(\mu_{B}, L_{A}\right)-P\left(\mu_{B}, L_{B}\right)
$$

or as

$$
R=P\left(\mu_{A}, L_{A}\right)-P\left(\mu_{B}, L_{A}\right) .
$$

${ }^{13}$ This equation is a variant of Chen and Ravallion (2004). 
Table 6 Decision matrix of Kakwani and Pernia index

\begin{tabular}{lll}
\hline$\Gamma$ & $\Phi$ & Decision \\
\hline Positive & Positive & Absolute pro-poor growth \\
Positive & Negative & Absolute non pro-poor growth \\
Positive & Larger than 1 & Relatively pro-poor growth \\
Positive & Lower than 1 & Relatively non pro-poor growth \\
\hline
\end{tabular}

Source: Author

Following Kakwani (2000), I decompose the changes in welfare $P^{A}-P^{B}$ as

$$
\begin{aligned}
P^{A}-P^{B}= & 0.5\left[P\left(\mu_{A}, L_{A}\right)-P\left(\mu_{B}, L_{A}\right)+P\left(\mu_{A}, L_{B}\right)-P\left(\mu_{B}, L_{B}\right)\right] \\
& +0.5\left[\left(\mu_{B}, L_{A}\right)-P\left(\mu_{B}, L_{B}\right)+P\left(\mu_{A}, L_{A}\right)\right. \\
& \left.-P\left(\mu_{B}, L_{A}\right)\right]
\end{aligned}
$$

and then as

$$
P^{A}-P^{B}=G+R
$$

where $G$ is the average growth effect, and $R$ is the average income effect.

Based on this expression, Kakwani and Pernia (2000) introduced a pro-poor growth index to assess to what extent growth enables the poor to actively participate in and significantly benefit from it. This index is called the Kakwani and Pernia (2000) pro-poor index, $\Phi$, and it is expressed as the ratio of the changes in poverty to the change that would have been observed if inequality did not change. Algebraically, this index is given by

$$
\Phi=\frac{P^{A}-P^{B}}{G} .
$$

Depending on the values of $\gamma$ and $\Phi$, the Kakwani and Pernia (2000) index can be used to assess two types of pro-poor growth, namely, absolute pro-poor growth and relative pro-poor growth. Table 6 summarizes the decision matrix for the Kakwani and Pernia index.

Based on Kakwani and Pernia (2000) pro-poor index, Kakwani et al. (2003) further developed a pro-poor index, the Poverty Equivalent Growth Rate (PEGR) index, that adjusts for the change in the growth rate. The PEGR is thus defined as the growth rate that will result in the same observed level of poverty change had the actual growth process not been accompanied by any change in inequality. Algebraically, the PEGR is given by the product of Kakwani and Pernia (2000) pro-poor index $(\Phi)$ and the growth in average income $(\gamma)$. It can, therefore, be written as

$$
\gamma^{*}=\Phi \gamma
$$

According to this expression, growth is absolutely pro-poor if the PERG index is positive. Similarly, growth is relatively pro-poor if the PERG index exceeds the growth 
rate in average income. In the same way, Ravallion and Chen (2003) propose a measure of pro-poor growth using the mean growth rate of the poor as a measurement variable for the rate of pro-poor growth. They define the mean growth rate of the poor as the average growth in income of households below the poverty line. Thus, the Ravallion and Chen (2003) pro-poor index can be calculated as the mean of the growth rate of each percentile of the income distribution up to the headcount index, divided by the headcount index. This measure is equivalent to the actual growth rate multiplied by the ratio of the actual change in the Watts index to the change in the same index that would have occurred had growth been distribution neutral.

\subsection{Determinants of Pro-poor Growth}

The pro-poor growth framework described in the previous section is highly descriptive and has limited policy implications. The reason is that this framework helps only to identify the sources of poverty changes, and policies that can produce pro-poor effects. In order to design a comprehensive policy package for agricultural transformation, I go a step further by ascertaining the relative contribution of specific factors that can potentially increase the pro-poorness of agricultural modernization. I proceed as follows. I select one of the agricultural modernization strategies that produced pro-poor effects, and run regressions on its welfare changes. The regression model includes variables that capture the heterogeneity of agriculture production, such as household socioeconomic characteristics, farm structure, and farming system. ${ }^{14}$ This is because the sole purpose of these regressions is to describe the profile of pro-poor technological changes at the household level. I estimate separate regressions for households in rural and urban areas, as the determinants of pro-poor welfare gains, as well as the policy implications, might be different in these two areas. The empirical specification of the pro-poor technological change, $d W_{h} / y_{h}$, is

$$
d W_{h} / y_{h}=\beta_{0}+\beta_{1} X_{1 h}+\beta_{2} X_{2 h}+\beta_{3} X_{3 h}+\varepsilon_{i},
$$

where $X_{1 h}$ refers to household socioeconomic characteristics, $X_{2 h}$ represents the farm structure, and $X_{3 h}$ is a vector of other control variables. The vector of household socioeconomic characteristics includes household composition, the share of household members participating in off-farm activities, and some characteristics of the household head such as age and education. Farm structure is a vector of variables related to farm-labor relationship, gender, and access to land, farm tools, and access to credit. In the model, I allow for interaction effects between farm tools and access to credit (farm tools\#credit). This simultaneous effect of credit and farm tools intuitively indicates the role of credit for purchasing farm machineries and implements. Finally, I use three variables to control for household heterogeneity at regional level. These include farming system, household index, and regional unemployment rate. Farming system is a binary variable which classifies regions according to the production of cassava, the leading crop in DRC. It takes a value of 1 if the region contributes less

\footnotetext{
${ }^{14}$ Excluding those variables may increase the risk of endogeneity and produce biased and inconsistent OLS estimator.
} 
than 10 percent of total production of cassava, and 0 otherwise. ${ }^{15}$ Household index is a composite variable estimated by applying a factor analysis. It includes household assets and building materials, access to cleaned water, proximity to school and hospital, among others.

\section{Results and Discussion}

This section experiments and analyzes agricultural modernization strategies using the methodology presented in the previous section. While the impacts of these policies on pro-poor growth will be the focus of this analysis, it is important that I discuss first the macroeconomic and sectoral effects of the experiments. Section 5.1 describes the policies considered in this study, Sects. 5.2 and 5.3 present the results of the CGE model on the macroeconomic and sectoral variables, and Sects. 5.4 and 5.5 present the pro-poor effects.

\subsection{Policy Experiments}

I design experiments to examine policy options for the DRC to modernize its agriculture and increase the income and welfare of households. In addition to their impact on income, I analyze if those policy experiments are pro-poor. As I noted in the theoretical consideration, there are two schemes to modernize agriculture in DRC. These are agricultural mechanization and chemicalization. On the order hand, I complement this analysis with two scenarios of institutional changes that lead to an increase in the supply of inputs. This is because institutional change is a key to the success of agricultural modernization in DRC as transaction costs within the input supply system are very high and there are no subsidies for inputs. Table 7 summarizes the policies simulated under the five scenarios.

I conduct two sets of experiments to evaluate the pro-poorness of different agricultural modernization strategies. The first set of experiments focuses on technological change and includes three scenarios, of which two put emphasis on the mechanization policies that change the factor intensities in the production of agriculture goods, and one on the chemicalization policies that improve the efficiency in the use of chemicals. In Scenario 1, I assume that DRC adopts a capital-using technology in agriculture, increasing the capital intensity by 3 percent. Scenario 2 models the effects of a labor-using technology that increases the labor intensity by 10 percent. In Scenario 3, I implement a strategy for agriculture chemicalization. This scenario implies that DRC farmers apply organic chemicals and best practices to increase the effectiveness and efficiency of chemicals. This simulation also means that farmers invest in soil and water management to increase the effectiveness in the use of chemicals. Consequently, they can avoid the overuse of very expensive chemicals and increase their time or frequency on the farm. Technically, I implement this scenario as a joint simulation of a 10 percent reduction in the use of chemicals per unit of aggregate

${ }^{15}$ These regions are Kasaï Occidental, Kasaï Oriental, Maniema, South-Kivu, North-Kivu, and Kinshasa. 
Table 7 Design of policy experiments

\begin{tabular}{|c|c|c|}
\hline Scenarios & Description & Design \\
\hline Scenario 1 & Capital-using technical change & $\begin{array}{l}\text { Increase of capital intensity ( } 3 \%) \text { in } \\
\text { agriculture }\end{array}$ \\
\hline Scenario 2 & Labor-using technical change & $\begin{array}{l}\text { Increase of labor intensity }(10 \%) \text { in } \\
\text { agriculture }\end{array}$ \\
\hline \multirow[t]{2}{*}{ Scenario 3} & $\begin{array}{l}\text { Improving the agricultural resource base } \\
\text { (teach farmers how to better use fertilizer) }\end{array}$ & $\begin{array}{l}\text { Reduction }(10 \%) \text { of chemicals per unit of } \\
\text { aggregate intermediate input }\end{array}$ \\
\hline & & $\begin{array}{l}\text { Reduction }(20 \%) \text { of factor requirements per } \\
\text { unit of output }\end{array}$ \\
\hline \multirow[t]{2}{*}{ Scenario 4} & Reducing fertilizer sourcing costs & $\begin{array}{l}\text { Reduction }(50 \%) \text { of import trade margins for } \\
\text { chemicals }\end{array}$ \\
\hline & & $\begin{array}{l}\text { Reduction }(50 \%) \text { of domestic trade margins } \\
\text { for chemicals }\end{array}$ \\
\hline \multirow[t]{2}{*}{ Scenario 5} & Reducing fertilizer distribution costs & $\begin{array}{l}\text { Reduction }(50 \%) \text { in import transportation } \\
\text { costs for chemicals }\end{array}$ \\
\hline & & $\begin{array}{l}\text { Reduction }(50 \%) \text { in domestic transportation } \\
\text { costs for chemicals }\end{array}$ \\
\hline
\end{tabular}

Source: Author

intermediate input and 20 percent increase in the factor requirement per agriculture output.

The second set of experiments considers a change in input markets related institutions. New institutions improve farmers' ability to access fertilizers and chemicals by reducing transaction costs in the procurement of inputs. The first experiment (Scenario 4) consists of reducing the fertilizers and pesticides sourcing costs by lowering imports and domestic trade margins by 50 percent. This can be achieved by cutting out the middlemen or breaking the monopoly in the distribution of agriculture inputs. Lastly, Scenario 5 models the effects of reducing fertilizers and pesticides transportation costs through the improvement of road and rail infrastructure and conditioning of products. In the model, I simulate the reduced fertilizer distribution costs scenario by assuming a 50 percent reduction in imports and domestic transportation costs of fertilizer.

In these scenarios, I assume that the direct tax rates are fixed and government savings adjust endogenously to ensure that government accounts balance. For the saving-investment account, the balanced closure specifies aggregate investment and government consumption as fixed shares of total domestic absorption. To keep investment fixed as a proportion of total absorption, the marginal savings propensities of households and enterprises move freely and maintain balance between investment and savings. Under this closure, agricultural modernization affects investment, consumption and savings evenly to absorb the full effect of the shock. Thus, the magnitude of the change of household consumption depends on the magnitude of the shock on savings, which in turn depends on the changes in investment and government consumption. The foreign exchange closure assumes a flexible exchange rate maintains a fixed level of foreign savings, which is consistent with the floating exchange rate system adopted in the DRC. Labor is unemployed and mobile across sectors, given 
high unemployment rate among all labor categories. This assumption is justified, as there is an excess supply of labor. In this case, real wage is fixed and the level of employment adjusts to restore the equilibrium in the labor market. Capital, in turn, is sector-specific but fully employed. Finally, the producer price index of non-traded domestic output is the numéraire.

\subsection{Macroeconomic and Sector Effects}

Table 8 reports the macro results of policy experiments described in the previous section. As expected, the impact of agricultural modernization is an increase in the size of the Congolese economy. Under capital-using technological change (Scenario 1), real GDP increases by 1.83 percent and total absorption by 1.80 percent. Because of the saving-investment balanced closure, the increased total absorption forces total investment and government consumption to rise by 0.59 and 0.58 percent. The increase of total investment depends also on the increase in government savings (1.99), as public investment accounts for 41 percent of total investment. At the same time, enterprise and household saving rates decrease by 0.17 and 1.08 percent, respectively, to match the value of investment. Private consumption increases by 2.04 percent while household and enterprise savings increase by 0.42 and 2.01 percent. Despite the fall in household and enterprise saving rate, savings by these domestic non-governmental institutions increase because of the impact of capital-using technological change on income. As a result of increased absorption, imports and exports rise, leading to an appreciation of the exchange rate.

Labor-using technological change (Scenario 2) leads to a 2.19 percent increase in GDP. Under this scenario, private and government consumption increase by 2.44 and 0.36 percent, respectively. Contrary to capital-using technological change, laborusing technological change would cause an increase in household saving rate by 0.45 percent and firm saving rate by 0.07 percent. From a policy perspective, the increase in household saving rate implies more private sector involvement in economic activity. In the case of agricultural households, savings can be invested in non-farming activities as well as in fertilizers and seeds. Finally, the simulation reveals that the real exchange rate appreciates by 1.75 percent, while exports and imports increase by 0.59 and 0.55 percent.

Scenario 3 indicates the potential impact of an improved agricultural resource base. The first thing to observe is that GDP and total absorption increase by 1 and 0.98 percent. As expected, total investment, household and government consumption also increase, due to the balanced closure. However, government savings decrease by 1.07 percent to balance government account because of fixed tax rates. Hence, only household and enterprise savings fuel total investment. Household savings increase significantly, reaching 3.71 percent, while firm savings increase by 2.25 percent. The remarkable change in household savings is mainly due to the increase in household savings rate $(+2.36 \%)$ as opposed to 0.36 percent for enterprises. Under this scenario, exports and imports fall by 0.34 and 0.32 percent, respectively.

A reduced chemical sourcing costs and reduced fertilizer distribution costs (Scenarios 4 and 5) yield quite similar macroeconomic results. However, the reduced 


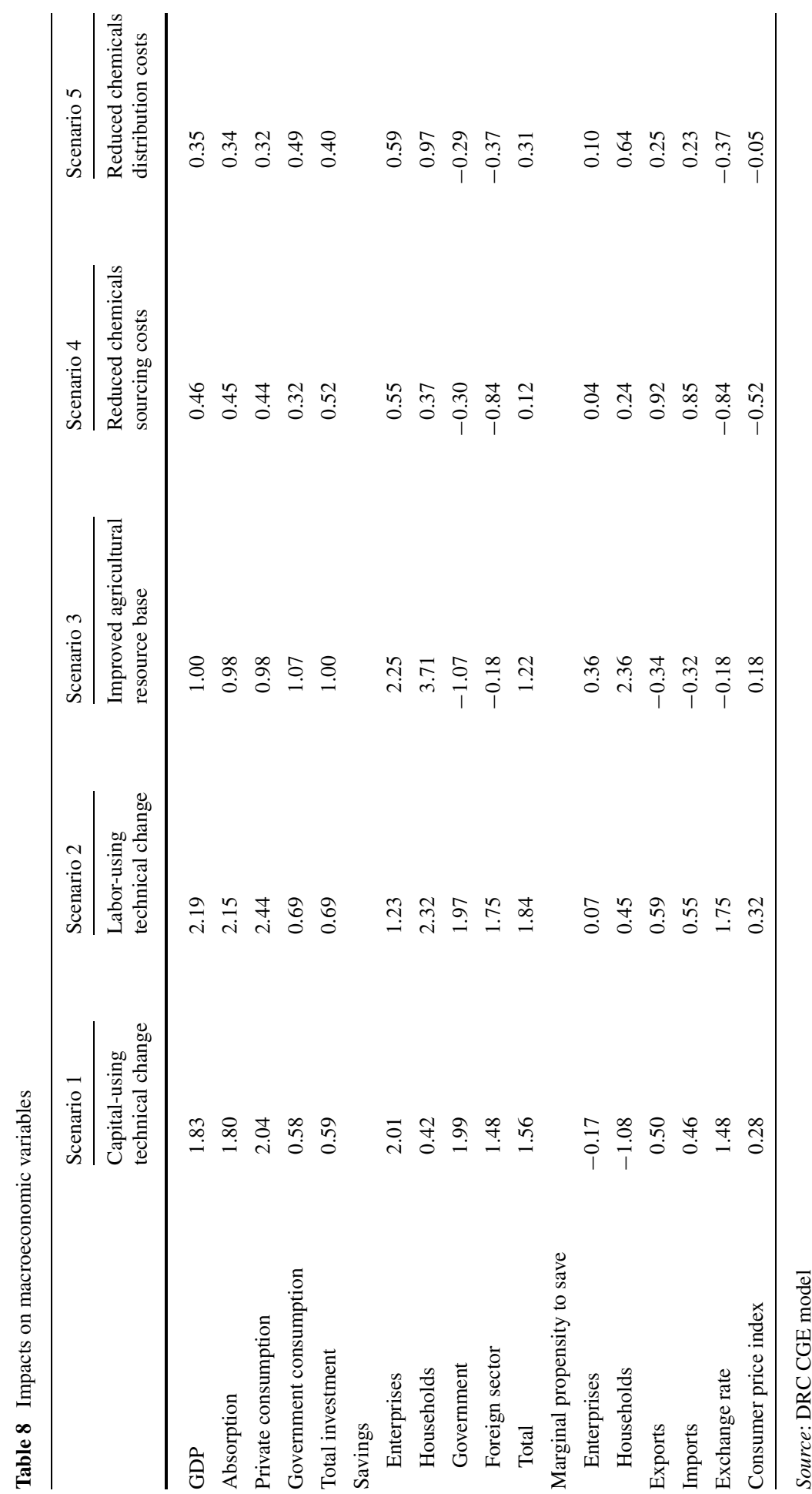


chemicals sourcing costs scenario gives better impacts, mainly in terms of GDP, private consumption and total investment. The simulation exercise reveals that GDP increases by 0.46 and 0.35 percent in both scenarios. Further, reduced chemicals sourcing costs (Scenario 4) raises private consumption and total investment by 0.44 and 0.52 percent, while, under reduced chemicals distribution costs (Scenario 5), one can observe a 0.32 percent increase of private consumption and a 40 percent increase in total investment.

At a disaggregated level, capital-using and labor-using technological changes in agriculture (Scenarios 1 and 2) generate spillover and lead to the expansion of other sectors in the Congolese economy. Nevertheless, it is worth mentioning that agroindustry related sectors benefit less from agriculture technological change than manufacturing and service related sectors. For example, Table 9 indicates that under capital-using technological change the value added of processed food and textiles increases by 0.46 and 0.47 percent as opposed to $2.19,1.40$, and 0.73 percent for wood products, utilities, and education and health. The small expansion of agro-industries is due to weak forward linkages from agriculture and high transaction costs. This result reflects the dual characteristic of DRC economy where agriculture and service sectors have strong linkages and play a more active role in the economy.

Concerning improved agricultural resource base (Scenario 3), Table 9 shows that the contraction of the chemical sector is very pronounced compared to textile and trade. When I reduce chemical sourcing costs (Scenario 4), the value added of wood, trade, and mining decrease by $1.53,1$, and 48 percent. Similarly, reducing chemical distribution costs (Scenario 5) causes a contraction of the transportation $(-0.37 \%)$ and mining sectors $(-0.13 \%)$. Note that these two scenarios produce a very small increase in agricultural value added. Agricultural value added increases by around 0.03 percent under reduced chemicals sourcing costs and around 0.02 percent under reduced chemicals distribution costs.

\subsection{Impacts on Factor Income and Consumption}

Table 10 indicates the impact of agricultural modernization on factor income. Results show that capital-using technological change (Scenario 1) is skill-biased as it favors workers with higher skill. Since I allow for unemployment and sectoral labor mobility, changes in factor income are a response to the change in employment. This result indicates that mechanization reduces the demand for rural low-skilled and semi-skilled workers and increases the demand for rural high-skilled workers. In rural areas, capital and high skill appear to be complementary as capital-intensive technology increases the demand for high-skilled workers. High-skilled workers are needed to operate tractors or to spray chemical as manual work is less needed. Thus, the remuneration for rural unskilled and semi-skilled labor decreases by 3.12 and 1.35 percent, while rural workers with high skill levels see their remuneration increase by 1.74 percent.

Labor-using technological change (Scenario 2) influences labor income by increasing the intensity of workers on the farm and, therefore, raising working hours and the frequency of work throughout the year. Scenario 2 in Table 10 indicates that labor-using technological change raises the returns for all factors involved in the production process. As expected, rural workers capture higher benefits. However, it is 


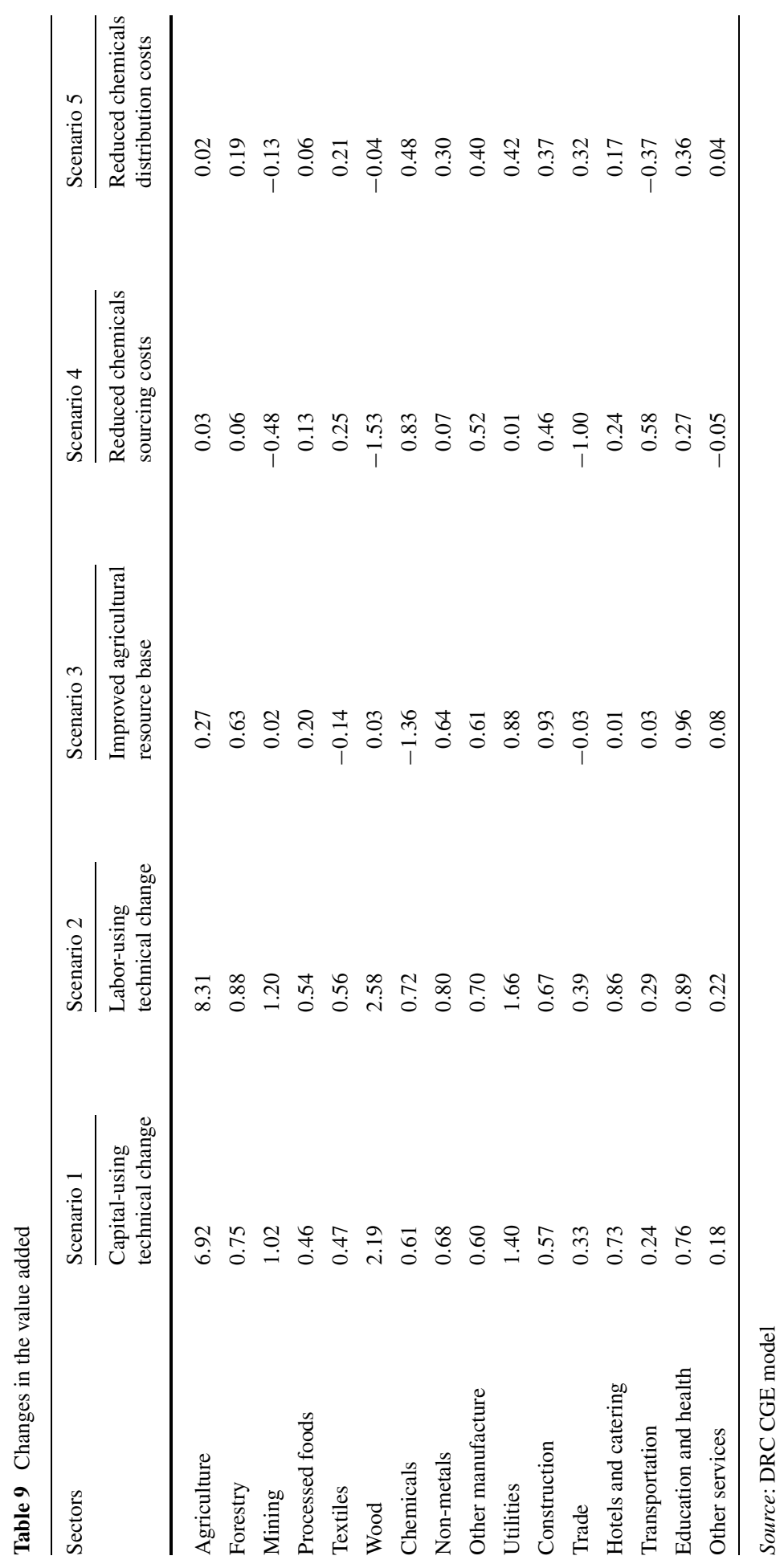




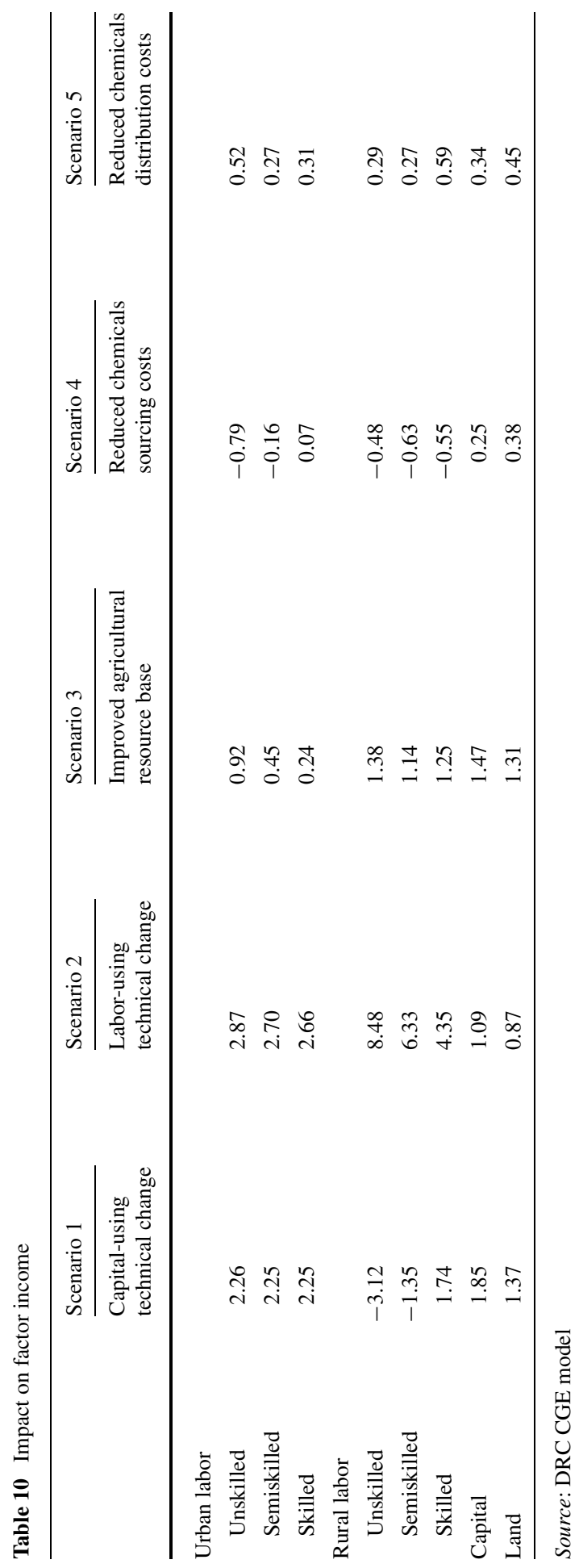


interesting to see that many of the gains go to workers with lower skills. This is because agriculture uses low-skilled workers intensively. In addition, this scenario has important implications for income distribution in both rural and urban areas, as gain differences in favor of workers with lower skill are non-negligible. For example, the remuneration of rural low-skilled workers increased by 8.48 percent whereas the return for semi-skilled and high-skilled laborers increased by 6.33 and 4.35 percent.

With regard to the improved agricultural resource base scenario, one can see that the results are qualitatively similar with labor-using technological change. Returns to labor are higher among rural workers than urban workers with similar skills. Under this scenario, urban low-skilled workers gain more than urban semi-skilled and highskilled workers do. Table 10 shows that returns to urban low-skilled labor increased by 0.92 percent while the returns for semi-skilled and high-skilled workers increased by 0.45 and 0.24 percent, respectively.

Turning the attention to the institutional changes scenarios, simulation results show that reducing fertilizer sourcing costs (Scenario 4) decreases the factor income for all labor categories, except for urban high-skilled labor. Reducing trade margins for fertilizers and pesticides lowers the price for agriculture intermediate inputs and increases agriculture producer price. Rising producer price in agriculture, in principle, should lead to an increase in factor income of rural workers as they are intensively employed in agriculture. However, the simulation indicates the fall of factor income. Income for urban low-skilled and semi-skilled labor falls by 0.79 and 0.16 percent, respectively. In rural areas, the remuneration for unskilled and semi-skilled labor drops by 0.48 and 0.65 percent, respectively, while high-skilled workers see their remuneration fall by 0.55 percent. There are two reasons for this. First, the impact of reduced fertilizer sourcing costs on agriculture value added is marginal, as agriculture uses outdated technology. From a policy standpoint, this indicates that technological changes play an important role in boosting agriculture output and productivity. Second and most importantly, lowering trade margins leads to a reduction of the producer price in the trade sector. This is due to the adjustment costs that occur when the Congolese marketing system transforms to a modern sector. Reduced producer price lowers the value-added price and thus wages of most of the labor categories since this sector is the second employer after agriculture. To counterbalance those negative effects on labor income, policies that break the monopoly of intermediaries in agricultural trade should also aim to increase operational efficiency by focusing on reducing the costs of inputs. This can be done when DRC public policymakers aim to improve ICT services to farmers by removing administrative barriers that prevent the development of mobile banking, mobile remittance and the exchange of agricultural input price information.

If improving institutions lowers the fertilizer distribution costs, as in Scenario 5, then the income of all production factors will increase. Under this scenario, the changes in income of rural workers are higher than those of urban areas. The highest increase is attributed to unskilled rural workers whose income increases by 1.38 percent whereas urban high-skilled labor's income increases only by 0.24 percent. Meanwhile, returns to capital and land are also high and reach 1.47 and 1.31 percent, respectively.

Moving on to the consumption effects of agriculture products, Table 11 indicates that mechanization of agriculture (Scenarios 1 and 2), leads to a decrease of the price 


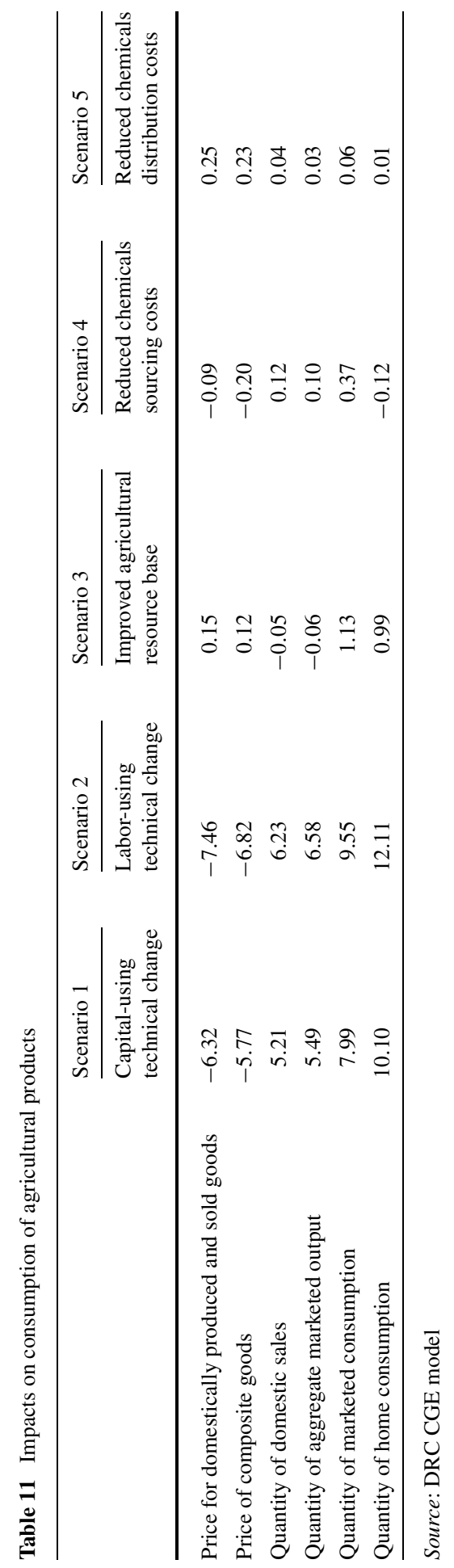


of agricultural products and an increase in the competitiveness of domestic products. Improving the agricultural resource base (Scenario 3) raises the market price of agricultural products, but this leads to an insignificant fall in sales. On the other hand, lowering chemicals sourcing costs (Scenario 4) reduces the market price of domestic production marginally, whereas reduced chemicals distribution costs (Scenario 5) increases the market price. Looking at consumption changes in Table 11, one can see that agricultural mechanization (Scenarios 1 and 2) increases household consumption of agricultural products from the market and their own production. Changes from home-produced consumption are significantly higher than the changes in consumption from the market. This is due to the high rate of subsistence agriculture and significant price differences due to transaction costs. It is interesting to see that in the case of an improved agricultural resource base (Scenario 3), home-produced consumption increases to a lesser extent than marketed consumption. Finally, lowered chemical sourcing costs (Scenario 4) reduces the consumption from own production and increases consumption from markets. In this scenario, home-produced consumption decreases by 0.12 percent while marketed consumption increases by 0.37 percent. For the reduced chemicals distribution costs scenario (Scenario 5), one can see that agriculture consumption from market and home production increases marginally. However, it is important to note that market consumption increases more than homeproduced consumption.

\subsection{Pro-poor Growth and Growth-Redistribution Decomposition}

In order to understand how inclusive the different schemes of technological and institutional changes are, in this section I apply the framework of pro-poor growth analysis on the welfare gains from the CGE results. Table 12 gives the estimates of the growth in average income and six pro-poor indices. The pro-poor indices include the Ravallion and Chen (2003) index, the Ravallion and Chen (2003) index minus $\gamma$, the Kakwani and Pernia (2000) index, the Kakwani and Pernia (2000) index minus 1 , the poverty-equivalent growth rate (PEGR) index, ${ }^{16}$ and the poverty-equivalent growth rate (PEGR) index minus $\gamma$. The Ravallion and Chen index, the Kakwani and Pernia index, and PEGR index constitute the absolute pro-poorness indices. They indicate whether the income of the poor has grown sufficiently after agricultural modernization for absolute poverty indices to fall. Therefore, a positive value of these indices indicates that growth led by agricultural modernization is absolutely pro-poor. The other three indices, the Ravallion and Chen index minus $\gamma$, the Kakwani and Pernia index minus 1 , and PEGR index minus $\gamma$, depicts the relative pro-poorness of agricultural modernization. They demonstrate whether the income of the poor has grown sufficiently after agricultural modernization to follow the overall increase in average income $(\gamma)$. In this case, agricultural modernization is relatively pro-poor if these indices take positive values.

Table 12 shows that all the three scenarios of agriculture modernization (Scenarios 1, 2, and 3) lead to an increase in average income. This result is consistent with

${ }^{16}$ This index is also called Kakwani et al. (2003). 


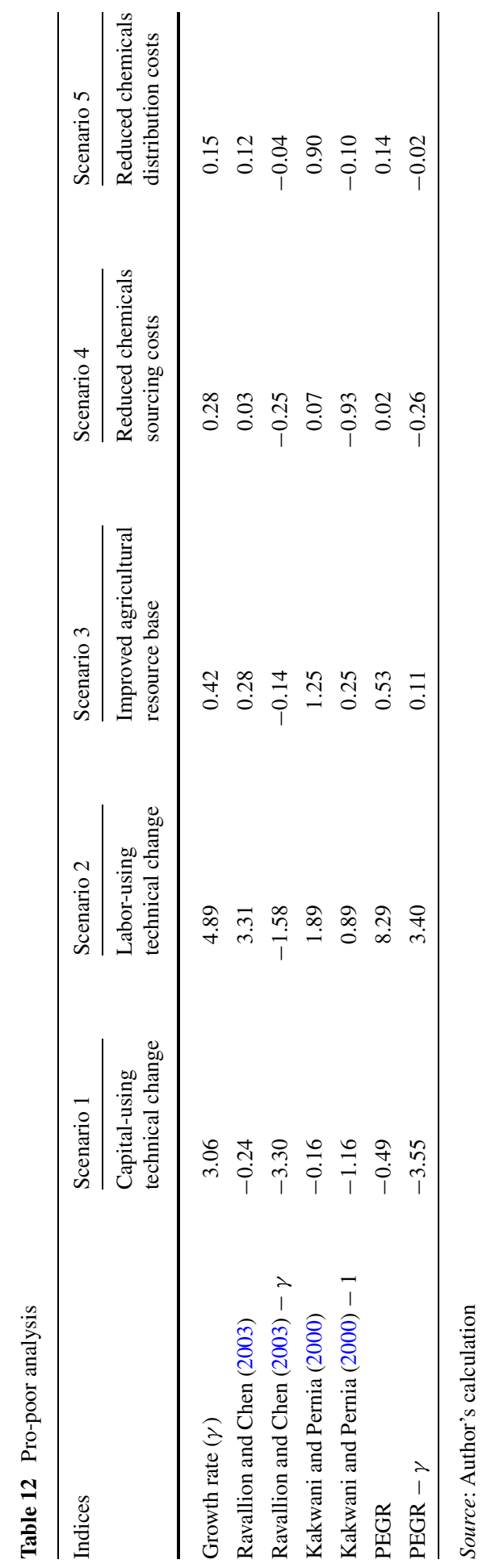


the macro effects discussed in the previous section. Table 12 further indicates that capital-using technological change (Scenario 1) is neither absolutely pro-poor nor relative pro-poor, as all of the six indices are negative. This implies that agriculture growth led by capital-using technological change decreases significantly the poor's relative shares in total consumption. In contrast, labor-using technological change (Scenario 2) is absolutely pro-poor. This is indicated by the positive sign of the Ravallion and Chen index, the Kakwani and Pernia index, and PEGR index. In terms of relative pro-poor effects, the Kakwani and Pernia index minus 1 and the PEGR index minus $\gamma$ show that the growth rate of the poor's income is enough to follow the growth rate in average income. This gives evidence that labor-using technical changeled growth is relatively pro-poor.

An improved agricultural resource base (Scenario 3), on the other hand, is absolutely pro-poor as all the three indices are greater than zero. Looking at this in a relative perspective, one can find that this policy is also pro-poor as the two relative pro-poor indices are positive. Turning our attention to the reduced chemical sourcing costs (Scenario 4), the absolute pro-poor indices are positive but not significant. However, the results on the relative pro-poor indices indicate that reduced chemical sourcing costs are not relatively pro-poor. Finally, the last column of Table 12 presents the pro-poorness of reduced chemical distribution costs (Scenario 5). The findings indicate that this scenario is absolutely pro-poor, but I have little evidence to conclude about the relative pro-poorness.

Next, I am interested in understanding the source of changes in poverty due to agricultural modernization. For this purpose, I decompose changes in poverty headcount ratio in terms of the effect of growth and changes in redistribution. The first column of Table 13 presents the growth-redistribution decomposition of the impact of capitalusing technological change (Scenario 1). Under this policy scenario, poverty headcount ratio increases by 2.07 percent. However, it is interesting to see that without any changes in inequality, capital-using technological change would reduce poverty by 1.05 percent. The increase in inequality $(+3.15 \%)$ cancels out the beneficial effect of capital-using technological change-led growth on poverty reduction. Thus, capital-using technological change leads to immiserizing growth. This finding corroborates the ideas that poverty reduction due to growth led by large-scale investment in agriculture depends on the initial level of inequality in income or distribution of assets. This is in line with previous research (Bourguignon and Morrisson 1998; de Janvry and Sadoulet 1996; Timmer 1997; Ravallion 1997; World Bank 2000), suggesting that the distribution of assets matters as it affects how well the poor connect to the growth process.

In contrast, labor-using technological change (Scenario 2 ) causes a reduction in the poverty headcount by 3.47 percent. 2.91 percent points of the 3.74 percentage point fall in poverty headcount are due to the growth effect. This means that if inequality did not change, poverty would be reduced by 2.91 percent. Thus, redistribution was responsible for 0.56 percentage points of poverty reduction. These findings are consistent with earlier evidence that unskilled labor-intensive agricultural activities have higher poverty-reducing capacity compared to high-skilled, capital-intensive activities (de Janvry and Sadoulet 2010; Loayza and Raddatz 2010). Similarly, an improved agricultural resource base (Scenario 3 ) reduces poverty by 2.71 percent. The growth 


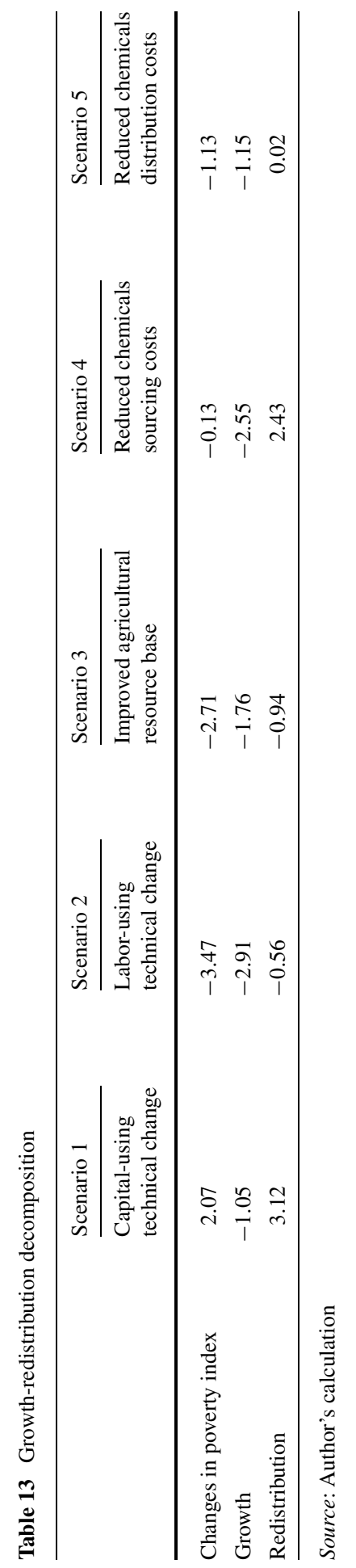


effect contributes to 1.76 percentage points in poverty changes while the income distribution effect contributes to 0.94 percentage point.

Concerning the growth-redistribution decomposition of reduced chemicals sourcing and distribution costs (Scenarios 4 and 5), one can observe in Table 13 that these scenarios have the same qualitative effects. They both lead to poverty reduction as would be expected. The growth effects of these policy scenarios contribute to reducing poverty whereas the redistribution effects contribute to increasing poverty. Nonetheless, the contribution of the redistribution effects is very low under reduced chemicals distribution costs compared to reduced chemical sourcing costs.

\subsection{Explaining Pro-poor Technological Change}

I extend the pro-poor growth analysis by looking at the determinants of pro-poor technological change at household level. Recall from the previous section, I found that labor-using technological change (Scenario 2) is absolutely and relatively pro-poor. Therefore, I run regressions on its predicted welfare gains to ascertain the relative contribution of relevant observed characteristics that can potentially increase the propoorness of technological change. Table 14 gives summary statistics on the predictors used in the regressions, broken down in rural and urban areas. In order to reduce any potential endogeneity problems of some of the predictors, I choose to include in the regressions only explanatory variables of potential relevance to agricultural and rural development policies in DRC. The first set of variables consist of household characteristics such household composition and the head's education and age. I also use the share of household members participating in off-farm activities as a proxy to measure the importance of off-farm activities and thus household income diversification. The second group of predictors is made up of farm structure variables such as farm-labor relationship, access to credit, farm tools possession, and rights on land. Finally, I use farming system, household index, and regional unemployment rate to control household heterogeneity at regional level. I define these predictors such that a positive sign implies better pro-poor welfare gains.

Table 15 shows the results on the determinants of pro-poor technological change derived from the regression model outlined in Eq. (12). They indicate that pro-poor welfare gains increase with household size in both rural and urban areas. However, the results suggest a strong negative and significant relationship between pro-poor welfare gains and household composition, especially concerning younger household members. For example, I find that rural and urban households with a larger share of kids tend to have lower welfare gains. This implies that the number of children also affects women's choice to work on the farm, as women are responsible for most of the on-farm tasks. Interestingly, I find that participation in off-farm activities is positively correlated with pro-poor welfare gains in rural areas and negatively in urban areas. This indicates that participation in off-farm activities has positive spillover effects on pro-poor agricultural technological change in rural areas. An important reason for this is that in rural areas, off-farm income is usually invested in modern inputs and insurance. This finding is in line with other studies that found that investment in nonfarm activities can benefit the agricultural sector (Dorward et al. 2004; de Janvry et al. 2005). 
Table 14 Summary statistics on predictors in the regression analysis

\begin{tabular}{|c|c|c|c|c|c|c|}
\hline \multirow[t]{2}{*}{ Variable } & \multicolumn{2}{|l|}{ Rural } & \multicolumn{2}{|l|}{ Urban } & \multicolumn{2}{|c|}{ National } \\
\hline & Mean & $\begin{array}{l}\text { Standard } \\
\text { deviation }\end{array}$ & Mean & $\begin{array}{l}\text { Standard } \\
\text { deviation }\end{array}$ & Mean & $\begin{array}{l}\text { Standard } \\
\text { deviation }\end{array}$ \\
\hline \multicolumn{7}{|l|}{ Household composition } \\
\hline Household size (log) & 1.576 & 0.62 & 1.493 & 0.60 & 1.531 & 0.61 \\
\hline Share of kids in the household & 0.181 & 0.18 & 0.195 & 0.18 & 0.189 & 0.18 \\
\hline Share of young in the household & 0.454 & 0.25 & 0.460 & 0.25 & 0.457 & 0.25 \\
\hline Share of adults in the household & 0.505 & 0.25 & 0.493 & 0.25 & 0.499 & 0.25 \\
\hline Participation in off-farm activities (share) & 0.578 & 0.28 & 0.888 & 0.21 & 0.720 & 0.29 \\
\hline Age of household head $(\log )$ & 3.741 & 0.31 & 3.699 & 0.33 & 3.718 & 0.32 \\
\hline Squared age $(\log )$ & 14.095 & 2.33 & 13.794 & 2.44 & 13.932 & 2.40 \\
\hline Years of education $(\log )$ & 2.099 & 0.53 & 1.758 & 0.59 & 1.923 & 0.59 \\
\hline Squared years of education (log) & 4.687 & 1.90 & 3.438 & 1.83 & 4.043 & 1.96 \\
\hline \multicolumn{7}{|l|}{ Farm structure } \\
\hline \multicolumn{7}{|l|}{ Farm-labor relationship } \\
\hline Household head or spouse & 0.250 & Binary & 0.632 & Binary & 0.457 & Binary \\
\hline Other household members & 0.025 & Binary & 0.027 & Binary & 0.026 & Binary \\
\hline Wage workers & 0.005 & Binary & 0.008 & Binary & 0.006 & Binary \\
\hline Sharecropper & 0.000 & Binary & 0.002 & Binary & 0.001 & Binary \\
\hline Other & 0.003 & Binary & 0.003 & Binary & 0.003 & Binary \\
\hline Male head with spouse without rights on land & 0.803 & Binary & 0.834 & Binary & 0.820 & Binary \\
\hline Female head holding rights on land & 0.003 & Binary & 0.001 & Binary & 0.002 & Binary \\
\hline Male head with spouse with rights on land & 0.004 & Binary & 0.007 & Binary & 0.005 & Binary \\
\hline Farm tools & 0.816 & Binary & 0.985 & Binary & 0.908 & Binary \\
\hline Credit & 0.092 & Binary & 0.118 & Binary & 0.106 & Binary \\
\hline \multicolumn{7}{|l|}{ Regional characteristics } \\
\hline Farming system & 0.333 & Binary & 0.154 & Binary & 0.236 & Binary \\
\hline Household index & 0.835 & 1.10 & -0.382 & 0.47 & 0.174 & 1.02 \\
\hline Unemployment rate & 5.654 & 4.68 & 3.539 & 2.30 & 4.506 & 3.74 \\
\hline
\end{tabular}

Source: Author's calculation

In addition, I found that pro-poor welfare gains are inverted U-shaped in age of household head in both rural and urban areas. This indicates that age has diminishing returns, meaning that it is beneficial for pro-poor growth until 39 in rural areas and 46 in urban areas, after which increases in age will decrease pro-poor welfare gains. The results for the years of education of the head are mixed. I find that education of the head has a very small and non-significant inverted U-shape effect in rural areas, but a significant U-shape effect in urban areas. To clearly highlight the substantive significance of education, I estimate and present in Fig. 8 the predictive margins for the years of education of the head in both rural and urban areas. ${ }^{17}$ Perhaps most striking

${ }^{17}$ For further details on marginal affects, see Cameron and Trivedi (2010). 
Table 15 Explaining pro-poor technological change led growth

\begin{tabular}{|c|c|c|}
\hline Variables & Rural & Urban \\
\hline \multicolumn{3}{|l|}{ Household composition } \\
\hline Household size (log) & $0.262^{* * *}$ & $0.327^{* * *}$ \\
\hline Share of kids in the household & $-0.216^{* * *}$ & $-0.308^{* * *}$ \\
\hline Share of young in the household & $-0.463^{* * *}$ & -0.021 \\
\hline Share of adults in the household & $-0.381^{* * *}$ & 0.112 \\
\hline Participation in off-farm activities (share) & $0.219^{* * *}$ & $-0.181^{* * *}$ \\
\hline Age of household head $(\log )$ & $7.549^{* * *}$ & $7.029^{* * *}$ \\
\hline Squared age $(\log )$ & $-1.030^{* * *}$ & $-0.916^{* * *}$ \\
\hline Years of education $(\log )$ & 0.007 & $-0.237^{*}$ \\
\hline Squared years of education (log) & -0.010 & $0.098^{* *}$ \\
\hline \multicolumn{3}{|l|}{ Farm structure } \\
\hline \multicolumn{3}{|l|}{ Farm-labor relationship } \\
\hline \multicolumn{3}{|l|}{ Household head or spouse (reference) } \\
\hline Other household members & 0.027 & 0.054 \\
\hline Wage workers & $0.415^{* * *}$ & -0.060 \\
\hline Sharecropper & 0.213 & 0.813 \\
\hline Other & 0.174 & $-0.472^{*}$ \\
\hline Male head with spouse without rights on land & $0.100^{* * *}$ & $0.137^{* * *}$ \\
\hline Female head holding rights on land & 0.004 & 0.351 \\
\hline Male head with spouse with rights on land & $0.183^{*}$ & $0.454^{*}$ \\
\hline Farm tools & 0.124 & -0.543 \\
\hline Credit & $0.166^{* *}$ & $0.495^{* * *}$ \\
\hline Farm tools\#credit (interaction term) & $0.171^{* *}$ & $0.571^{* * *}$ \\
\hline \multicolumn{3}{|l|}{ Regional characteristics } \\
\hline Farming system & $-2.606^{* * *}$ & $-0.660^{* * *}$ \\
\hline Household index & $0.189^{* * *}$ & $0.133^{* * *}$ \\
\hline Unemployment rate & $0.452^{* * *}$ & $0.127^{* * *}$ \\
\hline Observations & 4767 & 2192 \\
\hline Adjusted $R^{2}$ & 0.898 & 0.897 \\
\hline
\end{tabular}

${ }^{*} p<0.10,{ }^{* *} p<0.05,{ }^{* * *} p<0.01$

Source: Author's estimations

from Fig. 8, compared to the sign in Table 15, is the steady decline in pro-poor welfare gains until approximately 5 years of education. From a policy perspective, this finding means that every advance in post-primary education leads to higher pro-poor welfare gains.

With regard to farm structure, Table 15 indicates the importance of land tenure system, especially in favor of women. Results show that welfare gains tend to be higher when women hold rights on land. As can be seen, welfare gains increase by 0.183 percent when the head of household is a male and the spouse holds rights on the land. When the spouse does not hold rights on land, the increase in welfare gains is only 0.1 percent. It should be worth mentioning that this result is consistent in both rural 
Fig. 8 Predicative margins of education of the head

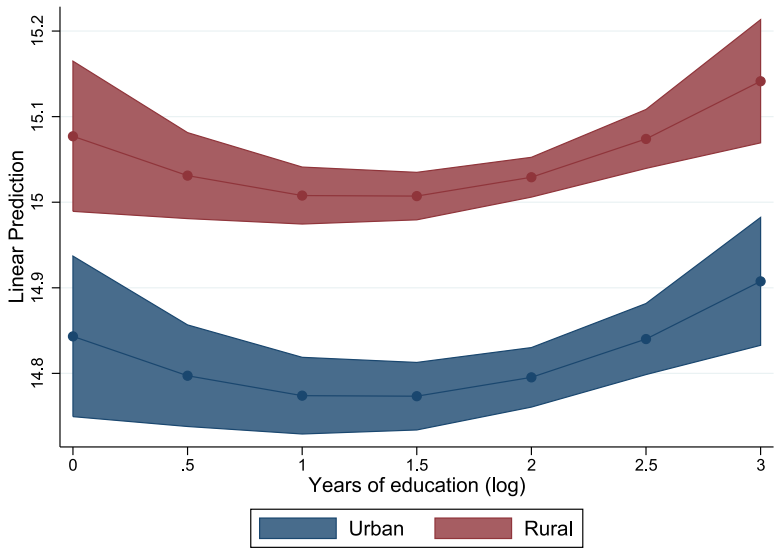

and urban areas, with a higher magnitude for urban areas. Further, farm tools have opposite sign in rural and urban areas but I fail to find any significant effect. However, what is interesting to notice from the estimation results is that the interaction between farm tools and credit is positive and significant. It is also worth mentioning that the coefficient of the interaction between farm tools and credit is larger than the effect of credit alone. Intuitively, this indicates the importance of establishing a specific credit for purchasing farm tools.

\subsection{Sensitivity Analysis}

A common feature of CGE model results is that they depend on assumptions made. In this section, I conduct a sensitivity analysis of the CGE model to ensure the robustness of the results. In the sensitivity analysis, I show the comparison for the simulation of capital-using and labor-using technical change with respect to the change of the production factor elasticities. Table 16 presents some of the results obtained when production elasticities of substitution increase or decrease by 5 percent.

I expected the magnitude of the results to differ because the nature of technical change and the assumption on the elasticities of substitution are the main drivers

Table 16 Explaining pro-poor technological change led growth

\begin{tabular}{|c|c|c|c|c|}
\hline & \multicolumn{2}{|c|}{ Capital-using technical change } & \multicolumn{2}{|c|}{ Labor-using technical change } \\
\hline & $\begin{array}{l}\rho^{\mathrm{p}} \text { decreases } \\
\text { by } 5 \%\end{array}$ & $\begin{array}{l}\rho^{\mathrm{p}} \text { increases } \\
\text { by } 5 \%\end{array}$ & $\begin{array}{l}\rho^{\mathrm{p}} \text { decreases } \\
\text { by } 5 \%\end{array}$ & $\begin{array}{l}\rho^{\mathrm{p}} \text { increases } \\
\text { by } 5 \%\end{array}$ \\
\hline GDP & 2.61 & 0.37 & 2.66 & 1.80 \\
\hline Absorption & 2.57 & 0.37 & 2.61 & 1.77 \\
\hline Private consumption & 2.92 & 0.41 & 2.97 & 1.97 \\
\hline Government consumption & 0.77 & 0.17 & 0.78 & 0.77 \\
\hline Total investment & 0.78 & 0.16 & 0.79 & 0.74 \\
\hline Exports & 0.67 & 0.14 & 0.68 & 0.67 \\
\hline Imports & 0.62 & 0.13 & 0.63 & 0.63 \\
\hline
\end{tabular}


of model results. ${ }^{18}$ Nonetheless, the qualitative results and the signs are robust to the changes in elasticities. Nevertheless, it is worth mentioning that the capital-using simulation appears to be less robust to higher production elasticities of substitution.

\section{Conclusions and Policy Implications}

In analyzing what are the better or worse models for agriculture modernization, this paper found that the adoption of capital-using technology leads to immiserizing growth through the redistribution effects. Results indicate that growth effects under this technological change reduced poverty slightly, while the redistribution effects canceled out the positive growth effects. This is because capital-using technological change increased output in all the sectors, but lowered rural unskilled and semiskilled income so that there was an overall increase in inequality. Rising inequality between rural workers with lower skill and the rest of workers emerged, a key factor explaining the anti-poor effects of capital-using technological change.

In contrast, labor-using technological change is found to be effective in producing pro-poor effects in both absolute and relative terms. The analysis also pinpoints the importance of labor-using technological change in improving urban-rural income disparities. Despite the large income change in favor of rural workers with lower skills, this result is partly due to the increase of home-produced consumption relative to the marketed consumption. The findings on poverty decomposition demonstrate that growth was responsible for more of the poverty changes than redistribution. This finding suggests that labor-using technological change can be independently sufficient in reducing poverty via the income growth effects. Under this scenario, I found that household and firm savings also increased. This can be an indication of future private investment in non-farm or fertilizer related activities. The improved agricultural resource base scenario produced similar pro-poor effects to those in labor-using technological change. Nonetheless, improved agricultural resource base has a limited potential to enhance growth outside agriculture.

In addition, I tested two scenarios of institutional changes that lead to an increase in supply of agriculture inputs. Firstly, the reduction of chemical sourcing costs implies lower income for most of the labor types and produces insignificant absolute pro-poor gains. From a policy perspective, this finding suggests that reducing trade margins should be implemented simultaneously with institutions and policies that increase farmers' market power and improve marketing efficiency. Secondly, reducing chemicals' distribution costs increases access to market for both producers and consumers, and it leads to an increase in income for all labor types. Consistently, this policy scenario produces absolute pro-poor effect but does not lead to income convergence.

I continued the analysis by investigating quantitatively the determinants of propoor growth, using welfare changes from labor-using technological change. Doing so, I found that participation in off-farm activities is statistically significant and strong determinant of pro-poor technological change in agriculture. Working as a wage

${ }^{18}$ See also Dawkins et al. (2001). 
worker improves pro-poor welfare gains only in rural areas. Other important findings show that women's land rights emerged as an important determinant of pro-poor welfare gains. Credit is positive and significant in rural and urban areas but I have not found significant effects for farm tools. Nonetheless, I found that there exist significant interactions between access to credit and farm tools in producing pro-poor welfare gains.

This research has intuitive findings for design and implementation of a pro-poor agriculture modernization strategy. The key policy recommendations arising from the paper are the following:

1. Public policymakers should promote the adoption of labor-using technologies to enable the use of cheap labor to intensify agriculture.

2. Public policymakers should increase farmers' capacity to evaluate, adapt, and disseminate proven technologies.

3. Public policymakers should increase investment in soil and water management methods, and in agriculture research and extension, to improve farmer's ability to use fertilizer efficiently.

4. Public policymakers should secure tenure among small-scale farmers and improve access to land, especially for women.

5. Public policymakers should help farmers organize themselves into cooperatives, break monopolies and cut rent seekers in seed supply and increase marketing efficiency.

6. Public policymakers should reform input supply networks and increase investment in input storage and road infrastructure. These steps should be implemented together with policies and institutions to remove credit constraint and increase farmers' ability to acquire tools and inputs.

\section{Competing Interests}

There are no conflicts of interest to declare.

Acknowledgements The author would like to thank the anonymous referees for their comments and suggestions.

\section{References}

African Union, ECA, AfDB (2012) Land policy in Africa: Central Africa regional assessment. AUC-ECAAfDB Consortium, Addis Ababa

Alvarez-Cuadrado F, Poschke M (2011) Structural change out of agriculture: labor push versus labor pull. Am Econ J Macroecon 3(3):127-158. doi:10.1257/mac.3.3.127

Annabi N, Cissé F, Cockburn J, Decaluwé B (2008) Trade liberalisation, growth and poverty in Senegal: a dynamic microsimulation CGE model analysis. Econ Prévis 186(5):117-131

Arndt C, Robinson S, Tarp F (2000) Marketing margins and agricultural technology in Mozambique. J Dev Stud 37(1):121-137

Bibi S, Cockburn J, Tiberti L, Fofana I (2010) Impacts of the global crisis and policy responses on child well-being: a macro-micro simulation framework. Innocenti working paper 2010-06, UNICEF Innocenti Research Centre, Florence and UNICEF Regional Office for West and Central Africa, Dakar 
Boccanfuso D, Kaboré ST (2004) Croissance, inégalité et pauvreté dans les années quatre-vingt-dix au Burkina Faso et au Sénégal. Rev écon Dév 2(12):9-35

Boccanfuso D, Coulibaly M, Timilsina GR, Savard L (2011) Economic and distributional impacts of biofuels in Mali. Cahiers de recherche 11-08, Departement d'Economique de la Faculte d'administration à l'Universite de Sherbrooke

Boccanfuso D, Coulibaly M, Timilsina GR, Savard L (2013a) Macroeconomic and distributional impacts of jatropha-based biodiesel in Mali. Policy research working paper 6500, The World Bank, Washington

Boccanfuso D, Savard L, Estache A (2013b) The distributional impact of developed countries' climate change policies on Senegal: a macro-micro CGE application. Sustainability 5(6):2727-2750

Bourguignon F, Morrisson C (1998) Inequality and development: the role of dualism. J Dev Econ 5:233257

Cameron AC, Trivedi PK (2010) Microeconometrics using Stata, revised edn. Stata Press, College Station

Chausse J-P, Kembola T, Ngonde R (2012) L'agriculture : pierre angulaire de l'économie de la RDC. In: Herderschee J, Samba DM, Tshibangu MT (eds) Résilience d'un Géant Africain : Accélérer la Croissance et Promouvoir l'Emploi en République Démocratique du Congo, Volume II : Etudes sectorielles. MÉDIASPAUL, Kinshasa, pp 1-97

Chen S, Ravallion M (2004) Welfare impacts of China's accession to the World Trade Organization. World Bank Econ Rev 18(1):29-57. doi:10.1093/wber/lhh031

Cleaver HM Jr (1972) The contradictions of the Green Revolution. Am Econ Rev 62(1/2):177-186.

Cogneau D, Robilliard A-S (2001) Croissance, distribution et pauvreté : un modèle de micro simulation en équilibre général applique à Madagascar. Working paper DT/2001/19, DIAL (Développement, Institutions \& Analyses de Long terme)

Collier P, Soludo CC, Pattillo C (2008) Economic policy options for a prosperous Nigeria. Palgrave Macmillan, New York

Cuffaro N (1997) Population growth and agriculture in poor countries: a review of theoretical issues and empirical evidence. World Dev 25(7):1151-1163. doi:10.1016/S0305-750X(97)00025-9

Das RJ (1998) The Green Revolution, agrarian productivity and labor. Int J Urban Reg Res 22(1):122-135. doi:10.1111/1468-2427.00127

Dawkins C, Srinivasan TN, Whalley J (2001) Calibration. In: James JH, Edward L (eds) Handbook of econometrics, vol 5. Elsevier, Amsterdam, pp 3653-3703 (chap 58)

de Janvry A, Sadoulet E (1996) Growth, inequality and poverty in Latin America: a causal analysis, 197094. Working paper 784, Department of Agricultural and Resource Economics, University of California at Berkeley

de Janvry A, Sadoulet E (2010) Agricultural growth and poverty reduction: additional evidence. World Bank Res Obs 25(1):1-20. doi:10.1093/wbro/lkp015

de Janvry A, Sadoulet E, Zhu N (2005) The role of non-farm incomes in reducing rural poverty and inequality in China. CUDARE working paper series 1001, Department of Agricultural and Resource Economics and Policy, University of California at Berkeley

Dervis K, de Melo J, Robinson S (1982) General equilibrium models for development policy. Cambridge University Press, New York

DFID (2006) Technology and its contribution to pro-poor agricultural development. DFID working paper 4, University of Greenwich

Dimaranan BV (ed) (2006) Global trade, assistance, and production: the GTAP 6 Data Base. Center for Global Trade Analysis, Purdue University

Dorward A, Fan S, Kydd J, Lofgren H, Morrison J, Poulton C, Rao N, Smith L, Tchale H, Thorat S, Urey I, Wobst P (2004) Institutions and policies for pro-poor agricultural growth. Dev Policy Rev 22(6):611-622

Eicher CK (1995) Zimbabwe's maize-based Green Revolution: preconditions for replication. World Dev 23(5):805-818. doi:10.1016/0305-750X(95)93983-R

FAO/WHO/UNU (2004) Human energy requirements. Report of a Joint FAO/WHO/UNU Expert Consultation, FAO food and nutrition technical report series 1

Freebairn D (1995) Did the Green Revolution concentrate incomes? A quantitative study of research reports. World Dev 23:265-279. doi:10.1016/0305-750X(94)00116-G

Glaeser B (1987) The Green Revolution revisited. Allen \& Unwin, London

Goldman A, Smith J (1995) Agricultural transformations in India and Northern Nigeria: exploring the nature of Green Revolutions. World Dev 23(2):243-263. doi:10.1016/0305-750X(94)00115-F

Griffin K (1979) The political economy of agrarian change: an essay on the Green Revolution, 2nd edn. Macmillan Press, London 
Hayami Y, Ruttan VW (1970) Factor prices and technical change in agricultural development: the United States and Japan, 1880-1960. J Polit Econ 78(5):1115-1141.

Hayami Y, Ruttan VW (1985) Agricultural development: an international perspective, revised and expanded edn. Johns Hopkins University Press, Baltimore

Hazell P (2009) The Asian Green Revolution. IFPRI discussion paper 00911, Washington

Hazell P, Ramasamy C (1991) The green revolution reconsidered: the impact of high-yielding rice varieties in South India. Johns Hopkins University Press, Baltimore

Herderschee J, Kaiser K-A, Mukoko DS (2012) Resilience of an African giant: boosting growth and development in the Democratic Republic of Congo. The World Bank, Washington

Huggins C (2010) Land, power and identity: roots of violent conflict in Eastern DRC. International Alert, London. http://www.international-alert.org/sites/default/files/DRC_LandPowerIdentity_EN_2010. pdf

Irz X, Lin L, Thirtle C, Wiggins S (2001) Agricultural productivity growth and poverty alleviation. Dev Policy Rev 19(4):449-466. doi:10.1111/1467-7679.00144

Jayne TS, Yamano T, Weber MT, Tschirley D, Benfica R, Chapoto A, Zulu B (2003) Smallholder income and land distribution in Africa: implications for poverty reduction strategies. Food Policy 28(3):253275

Kakwani N (2000) On measuring growth and inequality components of poverty with application to Thailand. J Quant Econ 16(1):67-80

Kakwani N, Pernia EM (2000) What is pro-poor growth? Asian Dev Rev 18(1):1-16

Kakwani N, Khandker S, Son HH (2003) Poverty equivalent growth rate: with applications to Korea and Thailand. Technical report, Economic Commission for Africa

Lambert PJ, Aronson JR (1993) Inequality decomposition analysis and the Gini coefficient revisited. Econ J 103(420):1221-1227. doi:10.2307/2234247

Lambert PJ, Decoster A (2005) The Gini coefficient reveals more. Discussion paper series (DPS) 05.08, Center for Economic Studies

Loayza NV, Raddatz C (2010) The composition of growth matters for poverty alleviation. J Dev Econ 93(1):137-151

Lofgren H, Cicowiez M, Diaz-Bonilla C (2013) MAMS - a computable general equilibrium model for developing country strategy analysis. In: Dixon PB, Jorgenson D (eds) Handbook of computable general equilibrium modeling, vol 1. Elsevier, Amsterdam

Long C (2011) Land rights in the Democratic Republic of Congo: a new model of rights for forestdependent communities? In: Helliker K, Murisa T (eds) Land struggles and civil society in Southern Africa. Africa World Press, Trenton

Magnac T (1991) Segmented or competitive labor markets? Econometrica 59:165-187

Mookherjee D, Shorrocks A (1982) A decomposition analysis of the trend in UK income inequality. Econ J 92(368):886-902. doi:10.2307/2232673

Morris M, Kelly V, Kopicki RJ, Byerlee D (2007) Fertilizer use in African agriculture: lessons learned and good practice guidelines. The World Bank, Washington

Mumvwela CM (2004) Le développement local au Kwango-Kwilu (RD Congo). Peter Lang Publishing, Bern

Ngai R, Pissarides C (2007) Structural change in a multi-sector model of growth. Am Econ Rev 97(1):429443

Nweke FI, Lutete D, Dixon AGO, Ugwu BO, Ajobo O, Kalombo N, Bukaka B (2000) Cassava production and processing in the Democratic Republic of Congo. Collaborative study of cassava in Africa, working paper 22, International Institute of Tropical Agriculture, Ibadan

OECD (2012) Agricultural policies for poverty reduction. OECD Publishing, Paris. doi:10.1787/ 9789264112902-en

Otchia C (2013a) How could industrial structure guide the choice of development strategy? A field of influence analysis for the Democratic Republic of Congo. Int J Econ Policy Stud 8(1):89-112

Otchia C (2013b) An integrated approach to trade policy, poverty and income distribution in the Democratic Republic of Congo: a CGE-microsimulation analysis. J Int Dev Stud 22(1):39-53

Otchia CS (2014) Distributional and poverty effects of agriculture trade liberalisation: the case of the Democratic Republic of Congo. Paper prepared for the UNCTAD Virtual Institute project on trade and poverty, UNCTAD-VI, Geneva

Ravallion M (1997) Can high inequality developing countries escape absolute poverty? Econ Lett 56:5157

Ravallion M, Chen S (2003) Measuring pro-poor growth. Econ Lett 78(1):93-99 
Ravallion M, Lokshin M (2008) Winners and losers from trade reform in Morocco. In: Bourguignon F, Bussolo M, Pereira da Silva L (eds) The impact of macroeconomic policies on poverty and income distribution: macro-micro evaluation techniques and tools, The World Bank and Palgrave, Washington, pp 27-60

Smale M (1995) "Maize is life": Malawi's delayed Green Revolution. World Dev 23(5):819-831. doi:10.1016/0305-750X(95)00013-3

Thirtle C, Townsend R, van Zyl J (1998) Testing the induced innovation hypothesis: an error correction model of South African agriculture. Agric Econ 19(1-2):145-157. doi:10.1016/ S0169-5150(98)00030-9

Thirtle C, Lin L, Piesse J (2003) The impact of research-led agricultural productivity growth on poverty reduction in Africa. Asia Latin Am World Dev 31(12):1959-1976. doi:10.1016/ j.worlddev.2003.07.001

Timmer P (1997) How well do the poor connect to the growth process? Mimeo

Vlassenroot K, Huggins C (2005) Land, migration and conflict in eastern DRC. In: Huggins C, Clover J (eds) From the ground up: land rights, conflict and peace in Sub-Saharan Africa. Institute for Security Studies, Pretoria, pp 115-194

World Bank (2000) World development report: attacking poverty. Oxford University Press, New York 